\title{
An Efficient Synthesis of Enamides from Ketones
}

\author{
Hang Zhao, Charles P. Vandenbossche, Stefan G. Koenig, \\ Surendra P. Singh,* and Roger P. Bakale \\ Chemical Process Research and Development, Sepracor Inc., \\ 84 Waterford Dr., Marlborough, Massachusetts 01752
}

\section{Supporting Information}

General. All reagents were obtained from commercial suppliers and were used without further purification. Only anhydrous solvents were used for the reactions and these were equally purchased from commercial suppliers. Triethylphosphine (caution: extremely pyrophoric and has a strong odor) was purchased from Cytec as $50 \mathrm{wt} \%$ solution in toluene. All the reactions were performed under nitrogen atmosphere. ${ }^{1} \mathrm{H}$ NMR and ${ }^{13} \mathrm{C}$ NMR were obtained from a Varian Mercury 400 spectrometer in deuterio-solvents with TMS as an internal standard at room temperature. Chemical shifts are reported in ppm from an internal standard on the $\delta$ scale. A Waters 2690 HPLC system equipped with Waters 2487 UV detector was used for in-process as well as chiral assays. The HPLC data were reported in area $\%$ and were not adjusted to weight $\%$. High resolution mass spectra were acquired on a Waters QTOF microsystem and externally by and M-Scan Inc. Elemental analyses were conducted by Galbraith Laboratories, Inc.

\section{3,4-Dihydronaphthalen-1(2H)-one oxime (Table 1, compound 4)}<smiles>O/N=C1\CCCc2ccccc21</smiles>

The mixture of $\alpha$-Tetralone (4.0 g, $26.8 \mathrm{mmol})$, sodium acetate (2.64 g, $32.2 \mathrm{mmol}, 1.2$ equiv) and hydroxylamine hydrochloride (2.42 g, $32.2 \mathrm{mmol}, 1.2$ equiv) in $\mathrm{MeOH}$ (12 $\mathrm{mL}$ ) was heated to reflux. After $1 \mathrm{~h}$, the reaction was allowed to cool to room temperature before diluting with ethyl acetate $(50 \mathrm{~mL}) .2 \mathrm{~N}$ sodium hydroxide $(13 \mathrm{~mL})$ was added 
prior to removal of solvent in vacuo. The residue was re-dissolved in $\mathrm{DI}_{2} \mathrm{O}(40 \mathrm{~mL})$ and EtOAc $(80 \mathrm{~mL})$. The aqueous layer was extracted with additional EtOAc $(50 \mathrm{~mL})$. The combined organic layers were washed with brine $(50 \mathrm{~mL})$ and concentrated to give a crude brown solid (4.4 g, 100\% yield). ${ }^{1} \mathrm{H}$ NMR (400 MHz, $\left.\mathrm{CDCl}_{3}\right) \delta 9.87$ (br, $\left.1 \mathrm{H}\right), 7.91$ $(\mathrm{dd}, 1 \mathrm{H}, J=8.0,1.2 \mathrm{~Hz}), 7.27(\mathrm{~m}, 2 \mathrm{H}), 7.18(\mathrm{dd}, 1 \mathrm{H}, J=7.6,0.8 \mathrm{~Hz}), 2.88(\mathrm{t}, 2 \mathrm{H}, J=6.8$ $\mathrm{Hz}), 2.79(\mathrm{t}, 2 \mathrm{H}, J=6.0 \mathrm{~Hz}), 1.91(\mathrm{~m}, 2 \mathrm{H}) .{ }^{13} \mathrm{C} \mathrm{NMR}\left(100 \mathrm{MHz}, \mathrm{CDCl}_{3}\right) \delta 155.3,139.8$, $130.3,129.2,128.6,126.4,124.0,29.7,23.9,21.2$. HRMS $(m / z)\left[\mathrm{M}+\mathrm{H}^{+}\right]$calcd for $\mathrm{C}_{10} \mathrm{H}_{12} \mathrm{NO}$ 162.0919; found, 162.0907.

\section{$N$-(3,4-Dihydronaphthalen-1-yl)acetamide (Table 1, compound 5)}

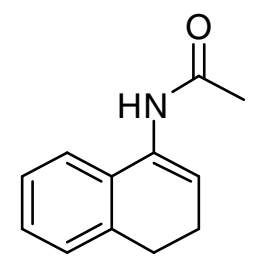

The solution of the above crude oxime $(1.0 \mathrm{~g}, 6.1 \mathrm{mmol})$ in toluene $(9.0 \mathrm{~mL})$ was purged with $\mathrm{N}_{2}$ for $30 \mathrm{~min}$. Neat $\mathrm{Et}_{3} \mathrm{P}(0.86 \mathrm{~g}, 1.1 \mathrm{~mL}, 7.3 \mathrm{mmol}, 1.2$ equiv $)$ was charged at room temperature. After stirring for $10 \mathrm{~min}$, acetic anhydride $(0.75 \mathrm{~g}, 0.69 \mathrm{~mL}, 7.3 \mathrm{mmol}, 1.2$ equiv) was added and the reaction heated to reflux. After $16 \mathrm{~h}$, the reaction mixture was cooled to room temperature and concentrated in vacuo. The residue was mixed with methanol $(15 \mathrm{~mL})$ and excess $\mathrm{K}_{2} \mathrm{CO}_{3}(1.3 \mathrm{~g})$. After $1 \mathrm{~h}$, methanol was removed in vacuo. The residue was dissolved in EtOAc $(100 \mathrm{~mL})$ and DI water $(50 \mathrm{~mL})$. The organic layer was separated, washed with DI water $(2 \times 50 \mathrm{~mL})$, concentrated and purified with flash column to give an off-white solid (1.0 g, 89\% yield). ${ }^{1} \mathrm{H}$ NMR (400 $\mathrm{MHz}, \mathrm{CDCl}_{3}$, mixture of rotamers) $\delta 7.11-7.21(\mathrm{~m}, 4 \mathrm{H}), 6.90(\mathrm{br}, 1 \mathrm{H}), 6.36(\mathrm{t}, 0.75 \mathrm{H}, J=4.8 \mathrm{~Hz})$, $5.94(\mathrm{br}, 0.25 \mathrm{H}), 2.82$ and $2.74(\mathrm{t}, 0.5 \mathrm{H}$ and $1.5 \mathrm{H}, J=8.0 \mathrm{~Hz}), 2.40$ and $2.34(\mathrm{~m}, 0.5 \mathrm{H}$ and $1.5 \mathrm{H}), 2.11$ and $1.93(\mathrm{~s}, 2.25 \mathrm{H}$ and $\left.0.75 \mathrm{H}) .{ }^{13} \mathrm{C} \mathrm{NMR} \mathrm{(100} \mathrm{MHz,} \mathrm{CDCl}_{3}\right) \delta$ 169.4, $136.7,131.5,131.5,128.1,127.7,127.4,126.8,126.3,125.9,122.0,120.7,119.7,27.5$, 27.2, 24.0, 22.5, 22.1, 20.2. HRMS $(\mathrm{m} / \mathrm{z})\left[\mathrm{M}+\mathrm{H}^{+}\right]$calcd for $\mathrm{C}_{12} \mathrm{H}_{14} \mathrm{NO}$ 188.1075; found, 188.1069 .

\section{2-Methyl-1-tetralone oxime (Table 2, entry 1, oxime)}




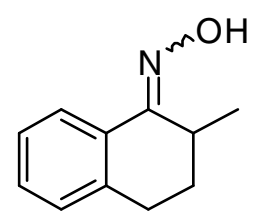

The ketone (10.0 g, $62.4 \mathrm{mmol})$ was dissolved in dry methanol $(45 \mathrm{~mL})$. Sodium acetate (6.1 g, $74.9 \mathrm{mmol}, 1.2$ equiv) and hydroxylamine hydrochloride (5.2 g, $74.9 \mathrm{mmol}, 1.2$ equiv) were added before heating the mixture to reflux. After $1.7 \mathrm{~h}$, the reaction was allowed to cool to ambient temperature and concentrated to dryness in vacuo. To the residue was added EtOAc $(100 \mathrm{~mL})$ and washed with DI water $(2 \times 50 \mathrm{~mL})$. The organic layer was dried $\left(\mathrm{Na}_{2} \mathrm{SO}_{4}\right)$, filtered and concentrated in vacuo to afford the crude product as an off-white solid (100\%), which was used in the next reaction without further purification: mp 89-91 ${ }^{\circ} \mathrm{C} .{ }^{1} \mathrm{H}$ NMR $\left(400 \mathrm{MHz}, \mathrm{CDCl}_{3}\right) \delta 10.12$ (br s, 1H), 7.85 (d, 1H, J $=7.8 \mathrm{~Hz}), 7.29-7.13(\mathrm{~m}, 3 \mathrm{H}), 3.73-3.63(\mathrm{~m}, 1 \mathrm{H}), 3.02-2.91(\mathrm{~m}, 1 \mathrm{H}), 2.70-2.62(\mathrm{~m}$, 1H), $2.04-1.93(\mathrm{~m}, 1 \mathrm{H}), 1.78-1.69(\mathrm{~m}, 1 \mathrm{H}), 1.23(\mathrm{~d}, 3 \mathrm{H}, J=6.9 \mathrm{~Hz}) .{ }^{13} \mathrm{C} \mathrm{NMR}(100$ $\left.\mathrm{MHz}_{\mathrm{CDCl}}\right) \delta 159.0,139.1,129.9,129.4,129.0,126.6,124.6,28.5,27.1,25.4,15.4$. $\operatorname{HRMS}(\mathrm{m} / \mathrm{z})[\mathrm{M}+\mathrm{H}]^{+}$: calcd for $\mathrm{C}_{11} \mathrm{H}_{13} \mathrm{NO}$ : 176.1075; found, 176.1071 .

\section{$N$-(2-Methyl-3,4-dihydronapthalen-1-yl)acetamide (Table 2, entry 1, enamide)}

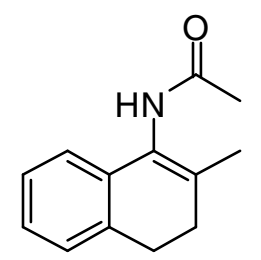

The oxime $(2.0 \mathrm{~g}, 11.4 \mathrm{mmol})$ was dissolved in toluene $(15 \mathrm{~mL})$. A $50 \%(\mathrm{w} / \mathrm{w}) \mathrm{Et}_{3} \mathrm{P}$ solution in toluene (4.0 mL, $13.7 \mathrm{mmol}, 1.2$ equiv) was added and the solution was allowed to stir 10 minutes at ambient temperature under nitrogen. Acetic anhydride (1.3 $\mathrm{mL}, 13.7 \mathrm{mmol}, 1.2$ equiv) was added and the solution heated to reflux to form a yellow solution. After refluxing $22 \mathrm{~h}$, the solution treated with $1 \%$ (by wt) aq $\mathrm{CuSO}_{4}(30 \mathrm{~mL})$, and extracted with EtOAc $(2 \times 50 \mathrm{~mL})$. The combined organic layers were concentrated in vacuo, the residue dissolved in $\mathrm{MeOH}(40 \mathrm{~mL})$ and the imide byproduct hydrolyzed with $2 \mathrm{~N} \mathrm{NaOH}(5 \mathrm{~mL})$. The mixture was stirred for $1 \mathrm{~h}$ at ambient temperature, concentrated in vacuo, the residue diluted with DI water $(50 \mathrm{~mL})$ and extracted twice with EtOAc. The combined organic layers were dried $\left(\mathrm{Na}_{2} \mathrm{SO}_{4}\right)$, filtered and concentrated 
in vacuo to afford the crude product. Column chromatography of the crude material (silica, 1:1:0.1\% Hex/EtOAc/NEt $\left.; \mathrm{R}_{\mathrm{f}}=0.21\right)$ yielded a white solid $(1.7 \mathrm{~g}, 74 \%): \mathrm{mp}$ 152-154 ${ }^{\circ} \mathrm{C} .{ }^{1} \mathrm{H}$ NMR $\left(400 \mathrm{MHz}, \mathrm{CD}_{3} \mathrm{OD}\right) \delta 7.14-7.05(\mathrm{~m}, 4 \mathrm{H}), 2.80(\mathrm{t}, 2 \mathrm{H}, J=8.4$, $7.6 \mathrm{~Hz}), 2.36$ (t, $2 \mathrm{H}, J=8.0,7.6 \mathrm{~Hz}), 2.15(\mathrm{~s}, 3 \mathrm{H}),$,1.83 (s, 3H). ${ }^{13} \mathrm{C} \mathrm{NMR}(100 \mathrm{MHz}$, $\left.\mathrm{CD}_{3} \mathrm{OD}\right) \delta 172.9,136.7,135.2,134.4,128.4,127.8,127.4,122.8,30.7,28.6,22.5,19.4$. HRMS $(\mathrm{m} / \mathrm{z})[\mathrm{M}+\mathrm{H}]^{+}$: calcd for $\mathrm{C}_{13} \mathrm{H}_{15} \mathrm{NO}$ : 202.1232; found, 202.1227.

\section{5-Methoxy-1-tetralone oxime (Table 2, entry 2, oxime)}

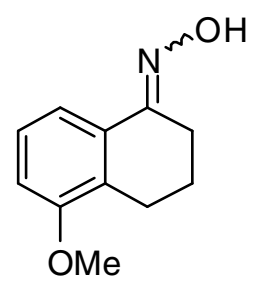

The ketone $(10.0 \mathrm{~g}, 56.7 \mathrm{mmol})$ was suspended in dry methanol $(41 \mathrm{~mL})$. Sodium acetate (5.6 g, $68.2 \mathrm{mmol}, 1.2$ equiv) and hydroxylamine hydrochloride (4.7 g, $68.2 \mathrm{mmol}, 1.2$ equiv) were added before heating the mixture to reflux. After $1 \mathrm{~h}$, the reaction was allowed to cool to room temperature and concentrated in vacuo to dryness. The resulting solid was slurried in DI water $(70 \mathrm{~mL})$, filtered and the cake washed with $(70 \mathrm{~mL})$ DI water and $(40 \mathrm{~mL})$ toluene to yield a tan solid (10.5 g. 97\%): $\mathrm{mp} 158-160{ }^{\circ} \mathrm{C} .{ }^{1} \mathrm{H}$ NMR $\left(400 \mathrm{MHz}, \mathrm{CDCl}_{3}\right) \delta 9.52(\mathrm{br} \mathrm{s}, 1 \mathrm{H}), 7.51(\mathrm{~d}, 1 \mathrm{H}, J=8.0 \mathrm{~Hz}), 7.17$ (t, $1 \mathrm{H}, J=8.0,8.0$ $\mathrm{Hz}), 6.83(\mathrm{~d}, 1 \mathrm{H}, J=8.0 \mathrm{~Hz}), 3.83(\mathrm{~s}, 3 \mathrm{H}), 2.83-2.72(\mathrm{~m}, 4 \mathrm{H}), 1.89-1.82(\mathrm{~m}, 2 \mathrm{H}) .{ }^{13} \mathrm{C}$ NMR $\left(100 \mathrm{MHz}, \mathrm{CDCl}_{3}\right) \delta 156.9,155.7,131.7,129.1,126.8,116.3,110.5,55.7,23.5$, 22.4, 21.0. HRMS $(\mathrm{m} / \mathrm{z})[\mathrm{M}+\mathrm{H}]^{+}$: calcd for $\mathrm{C}_{11} \mathrm{H}_{13} \mathrm{NO}_{2}$ : 192.1025; found, 192.1017 .

\section{$N$-(5-Methoxy-2-methyl-3,4-dihydronapthalen-1-yl)acetamide (Table 2, entry 2, enamide)}

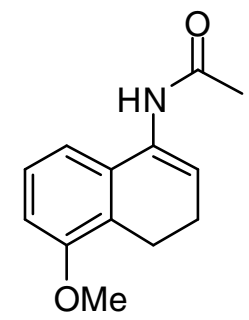

To the oxime $(3.0 \mathrm{~g}, 15.7 \mathrm{mmol})$ was added toluene $(21 \mathrm{~mL})$. A $50 \% \mathrm{Et}_{3} \mathrm{P}$ solution in toluene (5.4 mL, $18.9 \mathrm{mmol}, 1.2$ equiv) was added and the solution was allowed to stir 10 
minutes at ambient temperature under nitrogen. Acetic anhydride $(1.8 \mathrm{~mL}, 18.9 \mathrm{mmol}$, 1.2 equiv) was added and the solution heated to reflux to form a brown solution. After refluxing $23 \mathrm{~h}$, the solution was treated with $1 \%$ (by wt) aq $\mathrm{CuSO}_{4}(45 \mathrm{~mL})$ and EtOAc $(150 \mathrm{~mL})$, resulting in a slurry. The solids (product) were filtered and combined with the organic layer (also product) from the mother liquors and concentrated to dryness in vacuo. The solid residue was suspended in $\mathrm{MeOH}(60 \mathrm{~mL})$ and the imide byproduct was hydrolyzed with $2 \mathrm{~N} \mathrm{NaOH}(5 \mathrm{~mL})$. The mixture was stirred for $1 \mathrm{~h}$ at ambient temperature, then filtered. The solids were washed with 1:1 $(v / v) \mathrm{MeOH}:$ water which yielded a tan solid (2.6 g, 77\%): mp 183-185 ${ }^{\circ} \mathrm{C} .{ }^{1} \mathrm{H}$ NMR (400 MHz, DMSO-d 6 ) $\delta 9.07$ $(\mathrm{s}, 1 \mathrm{H}), 7.16(\mathrm{t}, 1 \mathrm{H}, J=8.0,7.6 \mathrm{~Hz}), 6.91(\mathrm{~d}, 1 \mathrm{H}, J=8.4 \mathrm{~Hz}), 6.86(\mathrm{~d}, 1 \mathrm{H}, J=8.0 \mathrm{~Hz})$, $6.15(\mathrm{~s}, 1 \mathrm{H}), 3.78(\mathrm{~s}, 3 \mathrm{H}), 2.64(\mathrm{t}, 2 \mathrm{H}, J=8.0,8.0 \mathrm{~Hz}), 2.25-2.22(\mathrm{~m}, 2 \mathrm{H}), 2.01(\mathrm{~s}, 3 \mathrm{H})$. ${ }^{13} \mathrm{C}$ NMR (100 MHz, DMSO-d 6 ) $\delta 168.8,155.5,132.8,132.3,126.3,123.3,119.2,115.0$, 110.3, 55.5, 23.3, 21.3, 19.2. HRMS $(\mathrm{m} / \mathrm{z})[\mathrm{M}+\mathrm{H}]^{+}$: calcd for $\mathrm{C}_{13} \mathrm{H}_{15} \mathrm{NO}_{2}$ : 218.1181; found, 218.1176.

\section{6-Methoxy-1-tetralone oxime (Table 2, entry 3, oxime)}

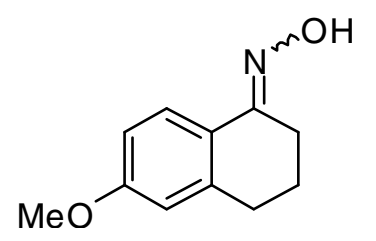

The ketone (10.0 g, $56.8 \mathrm{mmol})$ was suspended in dry methanol $(41 \mathrm{~mL})$. Sodium acetate (5.6 g, $68.2 \mathrm{mmol}, 1.2$ equiv) and hydroxylamine hydrochloride (4.7 g, $68.2 \mathrm{mmol}, 1.2$ equiv) were added before heating the mixture to reflux. After $1.5 \mathrm{~h}$, the reaction was allowed to cool to room temperature and concentrated to dryness in vacuo. The resulting solid was slurried in DI water $(70 \mathrm{~mL})$, filtered and the cake washed with $(70 \mathrm{~mL}) \mathrm{DI}$ water and $(40 \mathrm{~mL})$ toluene to yield a white crystalline solid (10.4 g. 96\%): mp 135-137 ${ }^{\circ} \mathrm{C} .{ }^{1} \mathrm{H}$ NMR $\left(400 \mathrm{MHz}, \mathrm{CDCl}_{3}\right) \delta 9.46($ br s, $1 \mathrm{H}), 7.82(\mathrm{~d}, 1 \mathrm{H}, J=8.8 \mathrm{~Hz}), 6.77(\mathrm{dd}, 1 \mathrm{H}$, $J=8.8,2.4 \mathrm{~Hz}), 6.66(\mathrm{~d}, 1 \mathrm{H}, J=2.4 \mathrm{~Hz}), 3.81(\mathrm{~s}, 3 \mathrm{H}), 2.83-2.72(\mathrm{~m}, 4 \mathrm{H}), 1.90-1.84$ $(\mathrm{M}, 2 \mathrm{H}) .{ }^{13} \mathrm{C} \mathrm{NMR}\left(100 \mathrm{MHz}, \mathrm{CDCl}_{3}\right) \delta 160.5,155.2,141.7,125.8,123.4,113.2,113.1$, 55.4, 30.3, 24.0, 21.6. HRMS $(\mathrm{m} / \mathrm{z})[\mathrm{M}+\mathrm{H}]^{+}$: calcd for $\mathrm{C}_{11} \mathrm{H}_{13} \mathrm{NO}_{2}$ : 192.1025; found, 192.1026. 


\section{$N$-(6-Methoxy-2-methyl-3,4-dihydronapthalen-1-yl)acetamide (Table 2, entry 3,}

enamide)

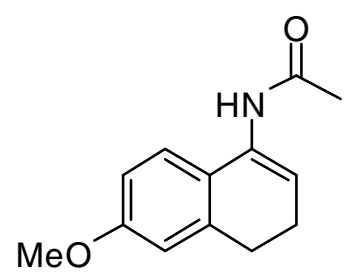

The oxime $(3.0 \mathrm{~g}, 15.7 \mathrm{mmol})$ was suspended in toluene $(21 \mathrm{~mL})$. A $50 \% \mathrm{Et}_{3} \mathrm{P}$ solution in toluene (5.4 mL, $18.9 \mathrm{mmol}, 1.2$ equiv) was added and the solution allowed to stir 10 minutes at ambient temperature under nitrogen. Acetic anhydride $(1.8 \mathrm{~mL}, 18.9 \mathrm{mmol}$, 1.2 equiv) was added and the solution heated to reflux to form a pale yellow solution. After refluxing $19 \mathrm{~h}$, the mixture was cooled to ambient temperature and treated with $1 \%$ (by wt) aq $\mathrm{CuSO}_{4}(45 \mathrm{~mL}) \mathrm{MeOH}(90 \mathrm{~mL})$ and $2 \mathrm{~N} \mathrm{NaOH}(10 \mathrm{~mL})$. The mixture was stirred for $1 \mathrm{~h}$ at ambient temperature to hydrolyze the imide byproduct. The mixture was concentrated to near dryness in vacuo, the residue dissolved in DI water $(50 \mathrm{~mL})$ and extracted with EtOAc $(2 \times 100 \mathrm{~mL})$. The combined organic layers were dried $\left(\mathrm{Na}_{2} \mathrm{SO}_{4}\right)$, filtered and concentrated in vacuo to afford a pink solid. Column chromatography of the crude material (silica, 1:1:0.1\% Hex/EtOAc/NEt $3 ; \mathrm{R}_{\mathrm{f}}=0.23$ ) yielded a white solid $(2.4 \mathrm{~g}$, 71\%): mp 128-130 ${ }^{\circ} \mathrm{C} .{ }^{1} \mathrm{H}$ NMR (400 MHz, $\left.\mathrm{CD}_{3} \mathrm{OD} / \mathrm{CDCl}_{3}\right) \delta 7.09(\mathrm{~d}, 1 \mathrm{H}, J=8.0 \mathrm{~Hz})$, $6.71-6.69(\mathrm{~m}, 2 \mathrm{H}), 5.99(\mathrm{t}, 1 \mathrm{H}, J=4.8,4.8 \mathrm{~Hz}), 3.78(\mathrm{~s}, 3 \mathrm{H}), 2.76(\mathrm{t}, 2 \mathrm{H}, J=8.4,7.6$ $\mathrm{Hz}), 2.37-2.32(\mathrm{~m}, 2 \mathrm{H}), 1.92(\mathrm{~s}, 3 \mathrm{H}) .{ }^{13} \mathrm{C} \mathrm{NMR}\left(100 \mathrm{MHz}, \mathrm{CD}_{3} \mathrm{OD} / \mathrm{CDCl}_{3}\right) \delta 172.5$, $160.0,139.3,132.9,125.7,123.9,120.2,114.5,111.7,55.7,28.8,23.3,23.1$. HRMS $(\mathrm{m} / \mathrm{z})[\mathrm{M}+\mathrm{H}]^{+}$: calcd for $\mathrm{C}_{13} \mathrm{H}_{15} \mathrm{NO}_{2}$ : 218.1181; found, 218.1166 .

\section{Cyclohexyl(phenyl)methanone oxime (Table 2, entry 4, oxime)}<smiles>O/N=C(/c1ccccc1)C1CCCCC1</smiles>

A mixture of ketone $(4.0 \mathrm{~g}, 20.8 \mathrm{mmol})$, sodium acetate $(2.05 \mathrm{~g}, 25.0 \mathrm{mmol}, 1.2$ equiv) and hydroxylamine hydrochloride $(1.74 \mathrm{~g}, 25.0 \mathrm{mmol}, 1.2$ equiv) in $\mathrm{MeOH}(62 \mathrm{~mL})$ was heated to reflux. After $1 \mathrm{~h}$, the reaction was allowed to cool to room temperature. The solvent was removed in vacuo. The residue was redissolved in $\mathrm{DI}_{2} \mathrm{O}(40 \mathrm{~mL})$ and 
ethyl acetate $(150 \mathrm{~mL})$. The organic layer was separated, washed with brine $(50 \mathrm{~mL})$ and concentrated to give a crude light yellow solid (4.3 g, 100\% yield). ${ }^{1} \mathrm{H}$ NMR (400 MHz, $\mathrm{CDCl}_{3}$, mixture of rotamers) $\delta 9.68(\mathrm{br}, 1 \mathrm{H}), 7.30-7.46(\mathrm{~m}, 5 \mathrm{H}), 3.35$ and $2.49(\mathrm{~m}$, $0.54 \mathrm{H}$ and $0.46 \mathrm{H}), 1.15-1.90(\mathrm{~m}, 10 \mathrm{H}) .{ }^{13} \mathrm{C} \mathrm{NMR}\left(100 \mathrm{MHz}, \mathrm{CDCl}_{3}\right) \delta 164.2,162.5$, 136.0, 133.9, 128.3, 128.2, 128.2, 128.2, 128.1, 128.0, 127.9, 127.4, 44.2, 38.1, 30.4, 29.2, 26.2, 26.1, 26.0, 26.0, 25.9. The rotamers exist. HRMS $(\mathrm{m} / \mathrm{z})\left[\mathrm{M}+\mathrm{H}^{+}\right]$calcd for $\mathrm{C}_{13} \mathrm{H}_{18} \mathrm{NO} 204.1388$; found, 204.1367.

\section{$N$-(cyclohexylidene(phenyl)methyl)acetamide (Table 2 , entry 4, enamide)}

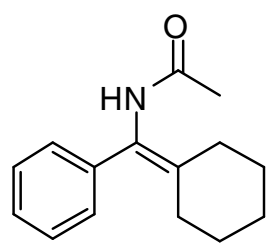

The solution of the crude oxime (from cyclohexyl phenyl ketone) $(1.0 \mathrm{~g}, 4.8 \mathrm{mmol})$ in toluene $(6.5 \mathrm{~mL})$ was purged with $\mathrm{N}_{2}$ for $30 \mathrm{~min}$. Neat $\mathrm{Et}_{3} \mathrm{P}(0.69 \mathrm{~g}, 0.86 \mathrm{~mL}, 5.8 \mathrm{mmol}$, 1.2 equiv) was charged at room temperature. After stirring for $10 \mathrm{~min}$, acetic anhydride ( $0.59 \mathrm{~g}, 0.55 \mathrm{~mL}, 5.8 \mathrm{mmol}, 1.2$ equiv) was added. The reaction mixture was heated to reflux. After $24 \mathrm{~h}$, the reaction mixture was cooled to room temperature and concentrated in vacuo. The residue was mixed with methanol $(20 \mathrm{~mL})$ and excess $\mathrm{K}_{2} \mathrm{CO}_{3}(1.0 \mathrm{~g})$. After 2h, methanol was removed in vacuo. The residue was dissolved in EtOAc (100 mL) and DI water $(50 \mathrm{~mL})$. The organic layer was separated, washed with DI water $(2 \times 50 \mathrm{~mL})$, concentrated and purified with flash chromatography to give a white solid (1.0 g, 90\% yield). ${ }^{1} \mathrm{H}$ NMR (400 MHz, $\mathrm{CDCl}_{3}$, mixture of rotamers) $\delta(\mathrm{ppm}) 7.22-7.36(\mathrm{~m}, 5 \mathrm{H})$, 6.70 and $6.58(\mathrm{br}, 0.33 \mathrm{H}$ and $67 \mathrm{H}), 2.20-2.35(\mathrm{~m}, 4 \mathrm{H}), 2.03$ and $1.79(\mathrm{~s}, 2 \mathrm{H}$ and $1 \mathrm{H})$, 1.56 - $1.65(\mathrm{~m}, 6 \mathrm{H}) .{ }^{13} \mathrm{C}$ NMR (100 MHz, $\left.\mathrm{CDCl}_{3}\right) \delta(\mathrm{ppm})$ 173.4, 168.3, 138.7, 138.5, 138.0, 137.4, 129.0, 129.0, 128.1, 127.9, 127.5, 127.1, 124.9, 31.0, 30.8, 30.7, 30.5, 28.0, 27.5, 27.3, 26.4, 26.3, 23.3, 20.6. HRMS $(m / z)\left[\mathrm{M}+\mathrm{H}^{+}\right]$calcd for $\mathrm{C}_{15} \mathrm{H}_{20} \mathrm{NO} 230.1545$; found, 230.1541 .

\section{1-(Naphthalen-2-yl)ethanone oxime (Table 2, entry 5, oxime)}




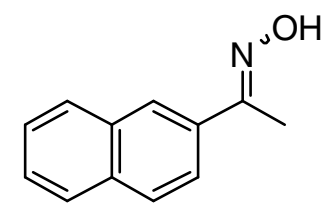

The ketone ( $4.56 \mathrm{~g}, 26.8 \mathrm{mmol})$ was slurried in dry methanol $(25 \mathrm{~mL})$. Sodium acetate (2.64 g, $32.2 \mathrm{mmol}, 1.2$ equiv) and hydroxylamine hydrochloride ( $2.23 \mathrm{~g}, 32.2 \mathrm{mmol}, 1.2$ equiv) were added before heating the mixture to reflux. After $2 \mathrm{~h}$, the reaction was allowed to cool to room temperature before diluting with toluene $(50 \mathrm{~mL}) .2 \mathrm{~N} \mathrm{NaOH}(13$ $\mathrm{mL}$ ) was added prior to removal of solvent in vacuo. The crude product was extracted from DI $\mathrm{H}_{2} \mathrm{O}(40 \mathrm{~mL})$ and EtOAc $(80 \mathrm{~mL})$, and again with EtOAc $(50 \mathrm{~mL})$. The combined organic layers were washed with brine $(50 \mathrm{~mL})$. Filtration through cotton, followed by concentration in vacuo furnished an off-white solid (5.0 g, 100\% yield), which was used for further processing without purification: mp $146-147{ }^{\circ} \mathrm{C} .{ }^{1} \mathrm{H}$ NMR (400 MHz, $\mathrm{CDCl}_{3}$ ): $\delta 9.00$ (br s, 1H), 8.04 (s, 1H), 7.87 (m, 4H), $7.52(\mathrm{~m}, 2 \mathrm{H}), 2.44$ (s, $3 \mathrm{H}) .{ }^{13} \mathrm{C}$ NMR $\left(100 \mathrm{MHz}, \mathrm{CDCl}_{3}\right): \delta 156.2,134.0,133.9,133.3,128.7,128.4,127.9$, 126.9, 126.6, 126.2, 123.5, 12.3. HRMS $(\mathrm{m} / \mathrm{z})[\mathrm{M}+\mathrm{H}]^{+}$: calcd for $\mathrm{C}_{12} \mathrm{H}_{12} \mathrm{NO}: 186.0919$; found, 186.0912 .

\section{$N$-(1-(Naphthalen-2-yl)vinylacetamide (Table 2, entry 5, enamide)}<smiles>C=C(NC(C)=O)c1ccc2ccccc2c1</smiles>

The oxime $(1.15 \mathrm{~g}, 6.20 \mathrm{mmol})$ was slurried in toluene $(9 \mathrm{~mL})$. A 50\% $\mathrm{Et}_{3} \mathrm{P}$ solution in toluene ( $2.15 \mathrm{~mL}, 7.44 \mathrm{mmol}, 1.20$ equiv) was added and the white slurry was allowed to stir 10 minutes under nitrogen. During acetic anhydride addition $(0.71 \mathrm{~mL}, 7.51 \mathrm{mmol}$, 1.21 equiv), the mixture formed a solution before returning to a slurry. This slurry was heated to reflux to form a yellow solution, which darkened over time to assume an orange color. After determining reaction completion at $10 \mathrm{~h}$, the mixture was cooled and treated with $1 \%$ (by wt) aq $\mathrm{CuSO}_{4}$, causing a change in color and consistency to a green-brown slurry. Dilution with EtOAc $(20 \mathrm{~mL})$ and separation of the layers was followed by 
extraction with EtOAc $(20 \mathrm{~mL})$. The combined organic layers were treated with $6 \mathrm{~N}$ $\mathrm{NaOH}(4 \mathrm{~mL})$ and $1 \mathrm{~N} n-\mathrm{Bu}_{4} \mathrm{NOH}$ in $\mathrm{MeOH}(0.03 \mathrm{~mL})$ to hydrolyze the byproduct imide. After stirring for several hours, the layers were separated and the organic layer was washed with water $(2 \times 15 \mathrm{~mL})$, dried over $\mathrm{Na}_{2} \mathrm{SO}_{4}$, filtered and concentrated to give the crude solid $(1.40 \mathrm{~g})$. Column chromatography (gradient to 70:30 Hex/EtOAc; $\mathrm{R}_{\mathrm{f}}=$ 0.22, 2:1 Hex/EtOAc/1\% $\mathrm{NEt}_{3}$ ) yielded an off-white solid (1.00 g, 76\%): $\mathrm{mp} 124-125{ }^{\circ} \mathrm{C}$. ${ }^{1} \mathrm{H}$ NMR (400 MHz, $\mathrm{CDCl}_{3}$ ): $\delta 7.80(\mathrm{~m}, 4 \mathrm{H}), 7.49$ (m, 3H), 7.38 (br s, 1H), $5.85(\mathrm{~s}, 1 \mathrm{H})$, $5.20(\mathrm{~s}, 1 \mathrm{H}), 2.05(\mathrm{~s}, 3 \mathrm{H}) .{ }^{13} \mathrm{C}$ NMR $\left(100 \mathrm{MHz}, \mathrm{CDCl}_{3}\right): \delta$ 169.7, 140.8, 135.7, 133.3, 128.6, 128.4, 127.9, 126.8, 126.7, 125.1, 124.4, 103.8, 24.6. HRMS $(\mathrm{m} / \mathrm{z})[\mathrm{M}+\mathrm{H}]^{+}$: calcd for $\mathrm{C}_{14} \mathrm{H}_{14} \mathrm{NO}$ : 212.1075; found, 212.1062 .

\section{Propiophenone oxime (Table 2, entry 6, oxime)}

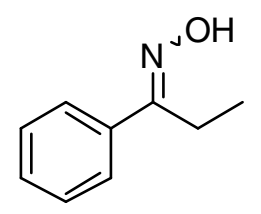

The ketone (3.60 g, $26.83 \mathrm{mmol})$ was slurried in dry methanol $(12 \mathrm{~mL})$. Sodium acetate (2.64 g, $32.2 \mathrm{mmol}, 1.2$ equiv) and hydroxylamine hydrochloride ( $2.24 \mathrm{~g}, 32.2 \mathrm{mmol}, 1.2$ equiv) were added before heating the mixture to reflux. After $2 \mathrm{~h}$, the reaction was allowed to cool to room temperature before diluting with toluene $(50 \mathrm{~mL}) .2 \mathrm{~N} \mathrm{NaOH}(13$ $\mathrm{mL}$ ) was added prior to removal of solvent in vacuo. The crude product was extracted from DI $\mathrm{H}_{2} \mathrm{O}(40 \mathrm{~mL})$ and EtOAc $(80 \mathrm{~mL})$, and again with EtOAc $(50 \mathrm{~mL})$. The combined organic layers were washed with brine $(50 \mathrm{~mL})$. Filtration through cotton followed by concentration in vacuo furnished a white solid (4.1 g, 99\% yield), which was used as such for further processing: $\mathrm{mp} 49-50{ }^{\circ} \mathrm{C} .{ }^{1} \mathrm{H}$ NMR $\left(400 \mathrm{MHz}, \mathrm{CDCl}_{3}\right): \delta 9.25$ (br s, 1H), $7.62(\mathrm{~m}, 2 \mathrm{H}), 7.41(\mathrm{~m}, 3 \mathrm{H}), 2.86(\mathrm{q}, 2 \mathrm{H}, J=7.7 \mathrm{~Hz}), 1.20(\mathrm{t}, 3 \mathrm{H}, J=7.7 \mathrm{~Hz})$. ${ }^{13} \mathrm{C}$ NMR $\left(100 \mathrm{MHz}, \mathrm{CDCl}_{3}\right): \delta 161.1,135.7,129.4,128.8,128.5,127.9,126.5,19.9$, 11.1. HRMS $(\mathrm{m} / \mathrm{z})[\mathrm{M}+\mathrm{H}]^{+}$: calcd for $\mathrm{C}_{9} \mathrm{H}_{12} \mathrm{NO}$ : 150.0919; found, 150.0921 .

\section{$N$-(1-Phenylprop-1-enyl)acetamide (Table 2, entry 6, enamide)}




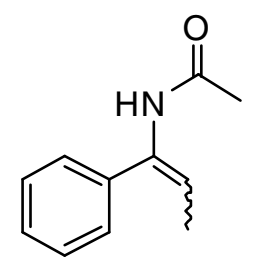

The oxime $(0.93 \mathrm{~g}, 6.20 \mathrm{mmol})$ was dissolved in toluene $(9 \mathrm{~mL})$. A 50\% $\mathrm{Et}_{3} \mathrm{P}$ solution in toluene $(2.15 \mathrm{~mL}, 7.44 \mathrm{mmol}, 1.20$ equiv) was added and the colorless solution was allowed to stir 10 minutes under nitrogen. Acetic anhydride $(0.71 \mathrm{~mL}, 7.51 \mathrm{mmol}, 1.21$ equiv) was added and the solution heated to reflux to form a light yellow solution. After determining reaction completion at $10 \mathrm{~h}$, the mixture was cooled and treated with $1 \%$ (by wt) aq $\mathrm{CuSO}_{4}$, causing a change to a green slurry. Dilution with EtOAc $(20 \mathrm{~mL})$ and separation of the layers was followed by extraction with EtOAc $(20 \mathrm{~mL})$. The combined organic layers were treated with $6 \mathrm{~N} \mathrm{NaOH}(4 \mathrm{~mL})$ and $1 \mathrm{~N} n-\mathrm{Bu}_{4} \mathrm{NOH}$ in $\mathrm{MeOH}(0.03$ $\mathrm{mL}$ ) to hydrolyze the byproduct imide. After stirring for several hours, the layers were separated and the organic layer was washed with water $(2 \times 15 \mathrm{~mL})$, dried over $\mathrm{Na}_{2} \mathrm{SO}_{4}$, filtered and concentrated to give the crude solid $(1.40 \mathrm{~g})$. Column chromatography (gradient to 70:30 Hex/EtOAc; $\mathrm{R}_{\mathrm{f}}=0.22,2: 1 \mathrm{Hex} / \mathrm{EtOAc} / 1 \% \mathrm{NEt}_{3}$ ) yielded a white solid (0.63 g, 58\%): mp 125-126 ${ }^{\circ} \mathrm{C},{ }^{1} \mathrm{H}$ NMR (400 MHz, $\left.\mathrm{CDCl}_{3}\right)(\sim 2: 1$ mixture of geometric isomers) $\delta 7.30(\mathrm{~m}, 5 \mathrm{H}), 6.65 / 6.59(\mathrm{br} \mathrm{s}, 1 \mathrm{H}), 6.04 / 5.96(\mathrm{q}, 1 \mathrm{H}, J=7.0 \mathrm{~Hz})$, 2.17 (s, 3H), 1.85/1.76 (d, 3H, $J=7.0 \mathrm{~Hz}) .{ }^{13} \mathrm{C} \mathrm{NMR}\left(100 \mathrm{MHz}, \mathrm{CDCl}_{3}\right) \delta 169.1,137.0$, 134.3, 129.0, 128.6, 128.2, 121.9, 115.4, 24.4, 14.1. HRMS $(\mathrm{m} / \mathrm{z})[\mathrm{M}+\mathrm{H}]^{+}$: calcd for $\mathrm{C}_{11} \mathrm{H}_{14} \mathrm{NO}$ : 176.1075; found, 176.1066 .

\section{2-Methyl-1-phenylpropan-1-one oxime (Table 2, entry 7, oxime)}<smiles>CC(C)C(=NO)c1ccccc1</smiles>

The ketone $(4.0 \mathrm{~g}, 27.0 \mathrm{mmol})$ was dissolved in dry methanol $(12 \mathrm{~mL})$. Sodium acetate (2.7 g, 32.9 mmol, 1.2 equiv) and hydroxylamine hydrochloride ( $2.3 \mathrm{~g}, 33.1 \mathrm{mmol}, 1.2$ equiv) were added before heating the mixture to reflux. After $1.5 \mathrm{~h}$, the reaction was allowed to cool to room temperature and added toluene $(50 \mathrm{~mL})$ and $2 \mathrm{~N} \mathrm{NaOH}(13 \mathrm{~mL})$. The phases were allowed to settle, and the aqueous phase was separated and discarded. 
The organic phase was washed with brine $(2 \times 50 \mathrm{~mL})$ and concentrated in vacuo to afford a colorless oil $\left(4.3 \mathrm{~g}, 99 \%\right.$ yield): ${ }^{1} \mathrm{H}$ NMR $\left(400 \mathrm{MHz}, \mathrm{CDCl}_{3}\right)(\sim 1: 1$ mixture of geometric isomers) $\delta 9.80(\mathrm{br} \mathrm{s}, 1 \mathrm{H}), 7.43-7.26(\mathrm{~m}, 10 \mathrm{H}), 3.67-3.53(\mathrm{~m}, 1 \mathrm{H}), 2.90-$ $2.76(\mathrm{~m}, 1 \mathrm{H}), 1.21(\mathrm{dd}, 3 \mathrm{H}, J=7.2,0.6 \mathrm{~Hz}), 1.12(\mathrm{dd}, 3 \mathrm{H}, J=7.2,0.6 \mathrm{~Hz}) .{ }^{13} \mathrm{C}$ NMR $\left(100 \mathrm{MHz}, \mathrm{CDCl}_{3}\right) \delta 164.9,163.3,135.9,133.9,128.7,128.6,128.32,128.29,127.9$, 127.7, 34.7, 27.9, 20.3, 19.5. HRMS $(\mathrm{m} / \mathrm{z})[\mathrm{M}+\mathrm{H}]^{+}$: calcd for $\mathrm{C}_{10} \mathrm{H}_{13} \mathrm{NO}: 164.1075$; found, 164.1046 .

\section{$N$-(2-Methyl-1-phenylprop-1-enyl)acetamide (Table 2, entry 7, enamide)}

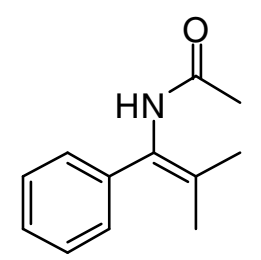

The oxime $(1.0 \mathrm{~g}, 6.1 \mathrm{mmol})$ was dissolved in toluene $(8 \mathrm{~mL})$. A 50\% $\mathrm{Et}_{3} \mathrm{P}$ solution in toluene ( $2.1 \mathrm{~mL}, 7.4 \mathrm{mmol}, 1.2$ equiv) was added and the solution was allowed to stir 10 minutes at ambient temperature under nitrogen. Acetic anhydride $(0.7 \mathrm{~mL}, 7.4 \mathrm{mmol}, 1.2$ equiv) was added and the solution heated to reflux to form a pale yellow solution. After refluxing $23 \mathrm{~h}$, the mixture was cooled to ambient temperature and concentrated in vacuo. The residue was treated with $20 \mathrm{~mL}$ of $1 \%$ (by wt) aq $\mathrm{CuSO}_{4}$, followed by $\mathrm{MeOH}(8 \mathrm{~mL})$ and $\mathrm{K}_{2} \mathrm{CO}_{3}(1.0 \mathrm{~g})$. The mixture was stirred for $1 \mathrm{~h}$ at ambient temperature then concentrated in vacuo. The residue was dissolved in EtOAc $(75 \mathrm{~mL})$ and washed with DI water $(2 \times 25 \mathrm{~mL})$. The organic layer was dried $\left(\mathrm{Na}_{2} \mathrm{SO}_{4}\right)$, filtered and concentrated in vacuo to afford the crude product as a tan oil. Column chromatography of the crude material (silica, 1:1:0.1\% Hex/EtOAc/NEt $; \mathrm{R}_{\mathrm{f}}=0.18$ ) yielded a white solid $(670 \mathrm{mg}$, 58\%): mp 100-102 ${ }^{\circ} \mathrm{C} .{ }^{1} \mathrm{H}$ NMR (400 MHz, $\left.\mathrm{CD}_{3} \mathrm{OD}\right) \delta 7.34-7.19$ (m, 5H), 2.00 (s, 3H), 1.77 (s, 6H). ${ }^{13} \mathrm{C}$ NMR (100 MHz, CD $\left.{ }_{3} \mathrm{OD}\right) \delta 171.9,140.2,131.1,130.3,129.7,129.4$, 129.0, 128.3, 22.7, 21.3, 20.9. HRMS $(\mathrm{m} / \mathrm{z})[\mathrm{M}+\mathrm{H}]^{+}$: calcd for $\mathrm{C}_{12} \mathrm{H}_{15} \mathrm{NO}: 190.1232$; found, 190.1223 .

\section{1-Indanone oxime (Table 2, entry 8, oxime)}




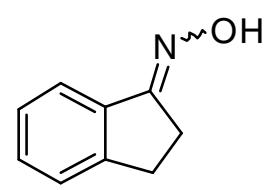

The ketone (14.6 g, $110.5 \mathrm{mmol})$ was dissolved in dry methanol $(80 \mathrm{~mL})$. Sodium acetate (10.9 g, $132.9 \mathrm{mmol}, 1.2$ equiv) and hydroxylamine hydrochloride (9.2 g, 132.4 mmol, 1.2 equiv) were added before heating the mixture to reflux. After $3 \mathrm{~h}$, the reaction was cooled to room temperature and concentrated in vacuo. The solid residue was suspended in DI water $(100 \mathrm{~mL})$, stirred for $1 \mathrm{~h}$, and filtered. The solids were washed with DI water $(97 \mathrm{~mL})$ and MtBE $(22 \mathrm{~g})$ to afford a white crystalline solid $(15.1 \mathrm{~g}, 93 \%$ yield): mp 146-148 ${ }^{\circ} \mathrm{C} .{ }^{1} \mathrm{H}$ NMR (400 MHz, CD $\left.3 \mathrm{OD}\right) \delta 7.63(\mathrm{~d}, 1 \mathrm{H}, J=8.0 \mathrm{~Hz}), 7.32(\mathrm{~d}$, $2 \mathrm{H}, J=4.0 \mathrm{~Hz}), 7.25-7.20(\mathrm{~m}, 1 \mathrm{H}), 3.04-3.01(\mathrm{~m}, 2 \mathrm{H}), 2.91-2.88(\mathrm{~m}, 2 \mathrm{H}) .{ }^{13} \mathrm{C} \mathrm{NMR}$ (100 MHz, $\left.\mathrm{CD}_{3} \mathrm{OD}\right) \delta 164.8,149.8,137.5,131.4,128.0,126.8,122.3,29.4,26.9$. HRMS $(\mathrm{m} / \mathrm{z})[\mathrm{M}+\mathrm{H}]^{+}$: calcd for $\mathrm{C}_{9} \mathrm{H}_{9} \mathrm{NO}: 148.0762$; found, 148.0759 .

\section{$N$-(1H-Inden-3-yl)acetamide (Table 2, entry 8, enamide)}

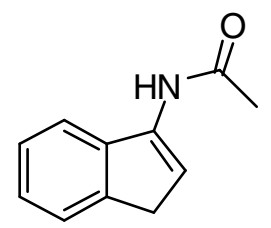

The oxime $(7.5 \mathrm{~g}, 51.0 \mathrm{mmol})$ was dissolved in toluene $(68 \mathrm{~mL})$. A 50\% $\mathrm{Et}_{3} \mathrm{P}$ solution in toluene (17.6 mL, $61.2 \mathrm{mmol}, 1.2$ equiv) was added and the solution was allowed to stir 10 minutes at ambient temperature under nitrogen. Acetic anhydride $(5.8 \mathrm{~mL}, 61.2$ mmol, 1.2 equiv) was added and the solution heated to reflux to form a red solution. After refluxing $5 \mathrm{~h}$, the mixture was cooled to ambient temperature and treated with 150 $\mathrm{mL}$ of $1 \%$ (by wt) aq $\mathrm{CuSO}_{4}$. The aqueous layer was extracted with EtOAc $(200 \mathrm{~mL})$, separated and the organic layer was concentrated to dryness. The solid residue was dissolved in $150 \mathrm{~mL}$ of $\mathrm{MeOH}$ and the imide byproduct was hydrolyzed with $2 \mathrm{~N} \mathrm{NaOH}$ $(10 \mathrm{~mL})$. The solution was concentrated in vacuo and the solid residue was dissolved in EtOAc $(200 \mathrm{~mL})$, washed with DI water $(2 \times 50 \mathrm{~mL})$, dried $\left(\mathrm{Na}_{2} \mathrm{SO}_{4}\right)$, filtered and concentrated to give the crude solid product $(7.8 \mathrm{~g})$. Column chromatography on $1.3 \mathrm{~g}$ sample of the crude material (silica, 1:1:0.1\% Hex/EtOAc/NEt $3 ; \mathrm{R}_{\mathrm{f}}=0.44$ ) yielded a yellow solid (1.29 g, 78\%): mp 132-134 ${ }^{\circ} \mathrm{C} .{ }^{1} \mathrm{H}$ NMR $\left(400 \mathrm{MHz}, \mathrm{CDCl}_{3}\right) \delta 7.57$ (br s, 
1H), $7.51-7.47(\mathrm{~m}, 1 \mathrm{H}), 7.23-7.22(\mathrm{~m}, 3 \mathrm{H}), 6.88(\mathrm{br} \mathrm{t}, 1 \mathrm{H}), 3.43(\mathrm{~m}, 2 \mathrm{H}), 2.24(\mathrm{~s}, 3 \mathrm{H})$. ${ }^{13} \mathrm{C}$ NMR $\left(100 \mathrm{MHz}, \mathrm{CDCl}_{3}\right) \delta 169.3,142.9,139.9,135.7,126.1,125.5,124.3,116.6$, 116.0, 36.7, 24.2. HRMS $(\mathrm{m} / \mathrm{z})[\mathrm{M}+\mathrm{H}]^{+}$: calcd for $\mathrm{C}_{11} \mathrm{H}_{11} \mathrm{NO}$ : 174.0919; found, 174.0904 .

\section{4-tert-Butylcyclohexanone oxime (Table 3, entry 1, oxime)}

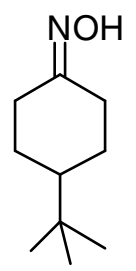

A mixture of ketone $(8.40 \mathrm{~g}, 54.4 \mathrm{mmol})$, sodium acetate $(4.92 \mathrm{~g}, 60.0 \mathrm{mmol}, 1.1$ equiv) and hydroxylamine hydrochloride ( $4.16 \mathrm{~g}, 60.0 \mathrm{mmol}, 1.1$ equiv) in $\mathrm{MeOH}(24 \mathrm{~mL})$ was heated to reflux. After $1 \mathrm{~h}$, the reaction was allowed to cool to room temperature and concentrated in vacuo. The residue was redissolved with EtOAc $(150 \mathrm{~mL})$ and $2 \mathrm{~N} \mathrm{NaOH}$ $(50 \mathrm{~mL})$. The organic layer was separated, washed with brine $(50 \mathrm{~mL})$ and concentrated to give a crude white solid $\left(9.2 \mathrm{~g}, 100 \%\right.$ yield). ${ }^{1} \mathrm{H}$ NMR $\left(400 \mathrm{MHz}, \mathrm{CDCl}_{3}\right.$, mixture of rotamers) $\delta 9.51(\mathrm{br}, 1 \mathrm{H}), 3.36(\mathrm{~m}, 1 \mathrm{H}), 2.43(\mathrm{~m}, 1 \mathrm{H}), 2.05(\mathrm{~m}, 1 \mathrm{H}), 1.92(\mathrm{~m}, 2 \mathrm{H}), 1.68$ (m, 1H), 1.19 (m, 3H), 0.85 (s, 9H). ${ }^{13} \mathrm{C}$ NMR $\left(100 \mathrm{MHz}, \mathrm{CDCl}_{3}\right) \delta 160.8,47.4,32.4$, $31.9,27.6,27.5,26.3,24.3$.

\section{$N$-(4-tert-Butylcyclohex-1-enyl)acetamide (Table 3, entry 1, enamide)}

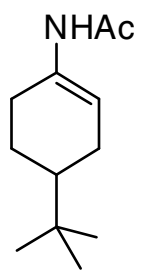

The solution of the crude oxime $(1.0 \mathrm{~g}, 6.5 \mathrm{mmol})$ in toluene $(6.0 \mathrm{~mL})$ was purged with $\mathrm{N}_{2}$ for $1 \mathrm{~h} .50 \mathrm{wt} \% \mathrm{Et}_{3} \mathrm{P}$ in toluene $(1.8 \mathrm{~g}, 2.2 \mathrm{~mL}, 7.8 \mathrm{mmol}, 1.2$ equiv) was charged at room temperature. After stirring for $10 \mathrm{~min}$, acetic anhydride $(0.99 \mathrm{~g}, 0.92 \mathrm{~mL}, 9.7 \mathrm{mmol}$, 1.5 equiv) was added, and the mixture heated to reflux. After $22 \mathrm{~h}$, the reaction was cooled to room temperature and concentrated in vacuo. The residue was mixed with methanol $(50 \mathrm{~mL})$ and excess $\mathrm{K}_{2} \mathrm{CO}_{3}$. After $15 \mathrm{~min}$, methanol was removed in vacuo. 
The residue was dissolved in EtOAc $(100 \mathrm{~mL})$ and DI water $(50 \mathrm{~mL})$. The organic layer was separated, washed with brine $(50 \mathrm{~mL})$, concentrated and purified by flash chromatography to give a semi-solid $\left(0.86 \mathrm{~g}, 71 \%\right.$ yield). ${ }^{1} \mathrm{H}$ NMR $\left(400 \mathrm{MHz}, \mathrm{CDCl}_{3}\right) \delta$ $6.71(\mathrm{br}, 1 \mathrm{H}), 6.01(\mathrm{~m}, 1 \mathrm{H}), 2.21(\mathrm{~m}, 1 \mathrm{H}), 2.12(\mathrm{~m}, 1 \mathrm{H}), 2.08(\mathrm{br}, 1 \mathrm{H}), 1.99(\mathrm{~s}, 3 \mathrm{H}), 1.81$ $(\mathrm{m}, 2 \mathrm{H}), 1.23$ (m, 2H), 0.84 (s, 9H). ${ }^{13} \mathrm{C}$ NMR $\left(100 \mathrm{MHz}, \mathrm{CDCl}_{3}\right) \delta 168.4,132.5,113.2$, 43.6, 32.1, 29.3, 27.1, 25.4, 24.3, 23.7. HRMS $(\mathrm{m} / \mathrm{z})\left[\mathrm{M}+\mathrm{H}^{+}\right]$calcd for $\mathrm{C}_{12} \mathrm{H}_{22} \mathrm{NO}$ 196.1701; found, 196.1702 .

\section{4-Phenylcyclohexanone oxime (Table 3, entry 2, oxime)}<smiles>ON=C1CCC(c2ccccc2)CC1</smiles>

A mixture of ketone $(5.00 \mathrm{~g}, 28.7 \mathrm{mmol})$, sodium acetate $(2.59 \mathrm{~g}, 31.6 \mathrm{mmol}, 1.1$ equiv) and hydroxylamine hydrochloride $(2.19 \mathrm{~g}, 31.6 \mathrm{mmol}, 1.1$ equiv) in $\mathrm{MeOH}$ (12 mL) was heated to reflux. After $1 \mathrm{~h}$, the reaction was allowed to cool to room temperature and concentrated in vacuo. The residue was redissolved with EtOAc $(150 \mathrm{~mL})$ and $2 \mathrm{~N} \mathrm{NaOH}$ $(50 \mathrm{~mL})$. The organic layer was separated, washed with brine $(50 \mathrm{~mL})$ and concentrated to give a crude white solid $\left(5.4 \mathrm{~g}, 99 \%\right.$ yield). ${ }^{1} \mathrm{H}$ NMR (400 $\mathrm{MHz}, \mathrm{CDCl}_{3}$, mixture of rotamers) $\delta 9.03(\mathrm{br}, 1 \mathrm{H}), 7.31(\mathrm{~m}, 2 \mathrm{H}), 7.23(\mathrm{~m}, 3 \mathrm{H}), 3.50(\mathrm{~m}, 1 \mathrm{H}), 2.79(\mathrm{~m}, 1 \mathrm{H}), 2.57$ $(\mathrm{m}, 1 \mathrm{H}), 2.29(\mathrm{~m}, 1 \mathrm{H}), 2.08(\mathrm{~m}, 2 \mathrm{H}), 1.91(\mathrm{~m}, 1 \mathrm{H}), 1.71(\mathrm{~m}, 2 \mathrm{H}) .{ }^{13} \mathrm{C} \mathrm{NMR}(100 \mathrm{MHz}$, $\left.\mathrm{CDCl}_{3}\right) \delta 159.7,145.7,128.5,128.3,126.8,126.7,126.3,126.0,43.7,34.0,32.8,32.6$, 32.0, 30.4, 24.2.

\section{N-(4-Phenylcyclohex-1-enyl)acetamide (Table 3, entry 2, enamide)}<smiles>CC(C)(C)NC1=CCC(c2ccccc2)CC1</smiles>

The solution of the crude oxime $(1.0 \mathrm{~g}, 5.3 \mathrm{mmol})$ in toluene $(6.0 \mathrm{~mL})$ was purged with $\mathrm{N}_{2}$ for $1 \mathrm{~h} .50 \mathrm{wt} \% \mathrm{Et}_{3} \mathrm{P}$ in toluene $(1.5 \mathrm{~g}, 1.8 \mathrm{~mL}, 6.3 \mathrm{mmol}, 1.2$ equiv) was charged at room temperature. After stirring for $10 \mathrm{~min}$, acetic anhydride $(0.81 \mathrm{~g}, 0.75 \mathrm{~mL}, 7.9 \mathrm{mmol}$, 
1.5 equiv) was added. The reaction mixture was heated to reflux. After $22 \mathrm{~h}$, the reaction was cooled to room temperature and concentrated in vacuo. The residue was mixed with methanol $(50 \mathrm{~mL})$ and excess $\mathrm{K}_{2} \mathrm{CO}_{3}$. After $30 \mathrm{~min}$, methanol was removed in vacuo. The residue was dissolved in EtOAc $(100 \mathrm{~mL})$ and DI water $(30 \mathrm{~mL})$. The organic layer was separated, washed with brine $(30 \mathrm{~mL})$ and concentrated to give the crude product (1.1 g). A white solid ( $0.53 \mathrm{~g}, 47 \%$ yield) was obtained by crystallization from $\mathrm{MeOH}$. The mother liquor was purified by column to give additional white solid $(0.20 \mathrm{~g})$, bringing the total isolated yield to $64 \% .{ }^{1} \mathrm{H}$ NMR $\left(400 \mathrm{MHz}, \mathrm{CD}_{3} \mathrm{OD}\right) \delta 7.24(\mathrm{~m}, 4 \mathrm{H})$, $7.15(\mathrm{~m}, 1 \mathrm{H}), 6.06(\mathrm{t}, 1 \mathrm{H}, J=2.8 \mathrm{~Hz}), 2.77(\mathrm{~m}, 1 \mathrm{H}), 2.34(\mathrm{~m}, 2 \mathrm{H}), 2.26(\mathrm{~m}, 1 \mathrm{H}), 2.22(\mathrm{~m}$, 1H), $1.98(\mathrm{~s}, 3 \mathrm{H}), 1.93(\mathrm{~m}, 1 \mathrm{H}), 1.85(\mathrm{~m}, 1 \mathrm{H}) .{ }^{13} \mathrm{C} \mathrm{NMR}\left(100 \mathrm{MHz}, \mathrm{CD}_{3} \mathrm{OD}\right) \delta$ 171.67, $147.85,134.41,129.43,127.87,127.15,114.27,41.09$, 33.40, 30.87, 29.11, 23.61. HRMS $(\mathrm{m} / \mathrm{z})\left[\mathrm{M}+\mathrm{H}^{+}\right]$calcd for $\mathrm{C}_{14} \mathrm{H}_{18} \mathrm{NO} 216.1388$; found, 216.1381 .

\section{3-(Hydroxyimino)-2-phenylbutanenitrile (Table 3, entry 3, oxime)<smiles>C/C(=N/O)C(C#N)c1ccccc1</smiles>

The mixture of ketone $(4.00 \mathrm{~g}, 24.6 \mathrm{mmol})$, sodium acetate $(2.22 \mathrm{~g}, 27.1 \mathrm{mmol}, 1.1$ equiv) and hydroxylamine hydrochloride (1.88 g, $27.1 \mathrm{mmol}, 1.1$ equiv) in $\mathrm{MeOH}$ (12 $\mathrm{mL}$ ) was heated to reflux. After $1 \mathrm{~h}$, the reaction was allowed to cool to room temperature and concentrated in vacuo. The residue was redissolved with EtOAc (150 $\mathrm{mL})$ and $2 \mathrm{~N} \mathrm{NaOH}(20 \mathrm{~mL})$. The organic layer was separated, washed with $\mathrm{DI}_{2} \mathrm{O}(20$ $\mathrm{mL}$ ) and concentrated to give a crude yellow oil (4.2 g, 98\% yield). ${ }^{1} \mathrm{H} \mathrm{NMR}(400 \mathrm{MHz}$, $\left.\mathrm{CDCl}_{3}\right) \delta 7.43(\mathrm{~m}, 2 \mathrm{H}), 7.30$ (m, 3H), 4.53 (br, 2H), 2.24 (s, 3H). ${ }^{13} \mathrm{C} \mathrm{NMR}(100 \mathrm{MHz}$, $\left.\mathrm{CDCl}_{3}\right) \delta 164.8,159.5,130.7,128.8,127.9,126.4,94.7,10.9$.

\section{(Z)- $N$-(1-Cyano-1-phenylprop-1-en-2-yl)acetamide (Table 3, entry 3, enamide)}

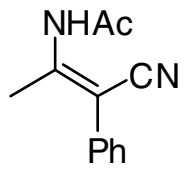

The solution of the crude oxime $(1.0 \mathrm{~g}, 5.7 \mathrm{mmol})$ in toluene $(6.5 \mathrm{~mL})$ was purged with $\mathrm{N}_{2}$ for $1 \mathrm{~h} .50 \mathrm{wt} \% \mathrm{Et}_{3} \mathrm{P}$ in toluene $(1.60 \mathrm{~g}, 2.0 \mathrm{~mL}, 6.9 \mathrm{mmol}, 1.2$ equiv) was charged at 
room temperature. After stirring for $10 \mathrm{~min}$, acetic anhydride $(0.70 \mathrm{~g}, 0.65 \mathrm{~mL}, 6.9 \mathrm{mmol}$, 1.2 equiv) was added and the reaction mixture heated to reflux. After $28 \mathrm{~h}$, the reaction was cooled to room temperature and quenched with $30 \%$ aq $\mathrm{CuSO}_{4}(1 \mathrm{~mL})$ solution. After stirring for $10 \mathrm{~min}$, EtOAc $(50 \mathrm{~mL})$ and DI water $(2 \mathrm{~mL})$ were charged. The organic layer was separated, washed with $2 \mathrm{~mL} 2 \mathrm{~N} \mathrm{NaOH}$ (aq) and $20 \mathrm{~mL}$ brine and concentrated to give the crude product (1.2 g). A green solid $(0.57 \mathrm{~g}, 50 \%)$ was obtained by crystallization from EtOAc. The mother liquor was purified on column to give an additional yellow solid (0.05 g), bringing the total isolated yield to 54\%. ${ }^{1} \mathrm{H}$ NMR (400 MHz, DMSO-d 6 ) $\delta 12.40(\mathrm{br}, 1 \mathrm{H}), 7.20-7.38(\mathrm{~m}, 5 \mathrm{H}), 2.25(\mathrm{~s}, 3 \mathrm{H}), 2.01(\mathrm{~s}, 3 \mathrm{H}) .{ }^{13} \mathrm{C}$ NMR (100 MHz, DMSO-d 6 ) $\delta 161.5,159.7,156.5,134.4,130.0,127.8,127.0,122.3$, 22.3, 20.8. HRMS $(m / z)\left[\mathrm{M}+\mathrm{H}^{+}\right]$calcd for $\mathrm{C}_{12} \mathrm{H}_{13} \mathrm{~N}_{2} \mathrm{O}$ 201.1028; found, 201.1019.

\section{2-Methylcyclohexanone oxime (Table 3, entry 4, oxime)}

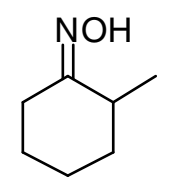

The mixture of ketone $(10.0 \mathrm{~g}, 89.2 \mathrm{mmol})$, sodium acetate $(8.04 \mathrm{~g}, 98.1 \mathrm{mmol}, 1.1$ equiv) and hydroxylamine hydrochloride (6.81 g, $98.1 \mathrm{mmol}, 1.1$ equiv) in $\mathrm{MeOH}$ (30 $\mathrm{mL}$ ) was heated to reflux. After $1 \mathrm{~h}$, the reaction was allowed to cool to room temperature and concentrated in vacuo. The residue was redissolved with EtOAc (150 mL), DI water $(50 \mathrm{~mL})$ and $2 \mathrm{~N} \mathrm{NaOH}(20 \mathrm{~mL})$. The organic layer was separated, washed with DI water $(50 \mathrm{~mL})$ and concentrated to give a crude yellow oil (11.4 g, 100\% yield). ${ }^{1} \mathrm{H}$ NMR (400 $\mathrm{MHz}, \mathrm{CDCl}_{3}$, mixture of rotamers) $\delta 9.92(\mathrm{br}, 1 \mathrm{H}), 3.10(\mathrm{~m}, 1 \mathrm{H}), 2.28(\mathrm{~m}, 1 \mathrm{H}), 1.68-$ $1.92(\mathrm{~m}, 4 \mathrm{H}), 1.42-1.52(\mathrm{~m}, 2 \mathrm{H}), 1.29(\mathrm{~m}, 1 \mathrm{H}), 1.09$ and $1.07(\mathrm{~s}, 2 \mathrm{H}$ and $1 \mathrm{H}) .{ }^{13} \mathrm{C} \mathrm{NMR}$ $\left(100 \mathrm{MHz}, \mathrm{CDCl}_{3}\right) \delta 163.6,163.0,37.1,35.5,31.5,28.2,26.3,26.6,25.9,24.6,23.9$, $20.3,16.7,16.1$.

\section{$N$-(2-Methylcyclohex-1-enyl)acetamide (Table 3, entry 4, enamide)}

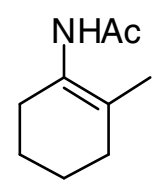


The solution of the crude oxime $(1.0 \mathrm{~g}, 7.9 \mathrm{mmol})$ in toluene $(6.0 \mathrm{~mL})$ was purged with $\mathrm{N}_{2}$ for $1 \mathrm{~h} .50 \mathrm{wt} \% \mathrm{Et}_{3} \mathrm{P}$ in toluene $(2.2 \mathrm{~g}, 2.7 \mathrm{~mL}, 9.4 \mathrm{mmol}, 1.2$ equiv) was charged at room temperature. After stirring for $10 \mathrm{~min}$, acetic anhydride $(1.6 \mathrm{~g}, 1.5 \mathrm{~mL}, 15.7 \mathrm{mmol}$, 2.0 equiv) was added and the reaction mixture heated to reflux. After $22 \mathrm{~h}$, the reaction was cooled to room temperature and concentrated in vacuo. The residue was mixed with methanol $(50 \mathrm{~mL})$ and excess $\mathrm{K}_{2} \mathrm{CO}_{3}$. After $1 \mathrm{~h}$, methanol was removed in vacuo. The residue was dissolved in EtOAc $(150 \mathrm{~mL})$ and DI water $(100 \mathrm{~mL})$. The organic layer was separated, washed with brine $(50 \mathrm{~mL})$, dried over $\mathrm{Na}_{2} \mathrm{SO}_{4}$, filtered and concentrated to give $0.90 \mathrm{~g}$ crude brown solid (5:1 regioisomeric ratio by ${ }^{1} \mathrm{H}$ NMR). A solid ( $0.34 \mathrm{~g}$, $28 \%$ ) was obtained by crystallization from heptanes. The mother liquor was purified on neutral $\mathrm{Al}_{2} \mathrm{O}_{3}$ to give additional yellow solid $(0.30 \mathrm{~g})$, bringing the yield of the major regioisomer to $54 \%$ yield. ${ }^{1} \mathrm{H} \mathrm{NMR}\left(400 \mathrm{MHz}, \mathrm{CDCl}_{3}\right) \delta 6.72(\mathrm{br}, 1 \mathrm{H}), 2.10(\mathrm{~m}, 2 \mathrm{H})$, $1.98(\mathrm{~m}, 5 \mathrm{H}), 1.59(\mathrm{~m}, 7 \mathrm{H}) .{ }^{13} \mathrm{C}$ NMR $\left(100 \mathrm{MHz}, \mathrm{CDCl}_{3}\right) \delta 173.1,168.3,131.8,126.8$, 126.6, 30.7, 30.6, 28.6, 23.4, 23.0, 22.9, 22.4, 22.3, 19.5, 18.3. Anal. calcd for $\mathrm{C}_{9} \mathrm{H}_{15} \mathrm{NO}$ : C, 70.55; H, 9.87; N, 9.14; found: C, 70.17; H, 10.16; N, 9.09.

\section{(S)-1-(3,4-Dichlorophenyl)-1,2-dihydronaphthalen-1(2H)-one oxime (Scheme 2, compound 7)}

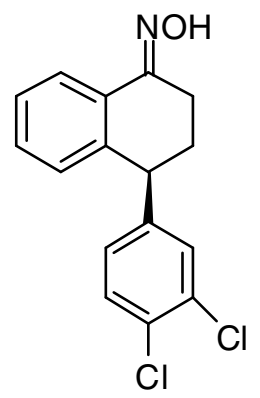

The suspension of a solution of $(S)$-tetralone $(56.0 \mathrm{~g}, 0.192 \mathrm{~mol})$, hydroxylamine hydrochloride (14.7 g, $0.212 \mathrm{~mol})$, and sodium acetate $(17.4 \mathrm{~g}, 0.212 \mathrm{~mol})$ in methanol $(168 \mathrm{~mL})$ was heated to reflux for $2 \mathrm{~h}$ under $\mathrm{N}_{2}$ atmosphere. After the reaction was deemed complete by HPLC, the mixture was concentrated in vacuo. The residue was diluted with toluene $(400 \mathrm{~mL})$ and $200 \mathrm{~mL}$ water. The organic layer was separated and washed with additional $200 \mathrm{~mL}$ water before concentration and drying to give crude solid oxime (58.9 g, 100\%), mp 117-120 ${ }^{\circ} \mathrm{C} .{ }^{1} \mathrm{H}$ NMR $\left(400 \mathrm{MHz}, \mathrm{CDCl}_{3}\right) \delta 9.40(\mathrm{br}, 1 \mathrm{H})$, $7.99(\mathrm{~m}, 1 \mathrm{H}), 7.38(\mathrm{~d}, 1 \mathrm{H}, J=8.0 \mathrm{~Hz}), 7.28(\mathrm{~m}, 2 \mathrm{H}), 7.19(\mathrm{~d}, 1 \mathrm{H}, J=2.4 \mathrm{~Hz}), 6.91(\mathrm{~m}$, 
$2 \mathrm{H}), 4.11(\mathrm{dd}, 1 \mathrm{H}, J=7.2,4.4 \mathrm{~Hz}), 2.82(\mathrm{~m}, 2 \mathrm{H}), 2.22(\mathrm{~m}, 1 \mathrm{H}), 2.05(\mathrm{~m}, 1 \mathrm{H}) .{ }^{13} \mathrm{C} \mathrm{NMR}$ $\left(100 \mathrm{MHz}, \mathrm{CDCl}_{3}\right) \delta 154.6,144.1,140.1,132.5,130.6,130.5,130.4,130.3,129.7,129.1$, $127.8,127.4,124.2,44.2,29.2,21.0$.

\section{$N$-((S)-1-(3,4-dichlorophenyl)-1,2-dihydronaphthalen-4-yl)acetamide (Scheme 2, compound 9)}

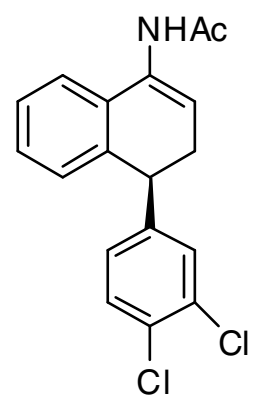

A solution of the crude oxime $(59 \mathrm{~g}, 0.193 \mathrm{~mol})$ in toluene $(500 \mathrm{~mL})$ was purged with $\mathrm{N}_{2}$ for $30 \mathrm{~min}$. Neat $\mathrm{Et}_{3} \mathrm{P}(25 \mathrm{~g}, 0.212 \mathrm{~mol})$ was charged. After stirring for $10 \mathrm{~min}$, acetic anhydride $(21.6 \mathrm{~g}, 20 \mathrm{~mL}, 0.212 \mathrm{~mol})$ was added. The reaction mixture was refluxed for $12 \mathrm{~h}$, monitored by HPLC. The reaction mixture was cooled to room temperature and $6 \mathrm{~N}$ aq $\mathrm{NaOH}(86 \mathrm{~mL}, 0.516 \mathrm{~mol})$ and $1.0 \mathrm{~N}(n-\mathrm{Bu})_{4} \mathrm{NOH}$ in methanol $(1.0 \mathrm{~mL})$ were charged. The hydrolysis of imide to enamide took about $3 \mathrm{~h}$. The organic layer was separated and diluted with EtOAc $(300 \mathrm{~mL})$ and $30 \mathrm{~mL}$ 2-BuOH. The diluted organic solution was washed with $1 \%$ aq $\mathrm{AcOH}$ solution $(300 \mathrm{~mL})$ and $3 \times 300 \mathrm{~mL}$ DI water, and concentrated to about $350 \mathrm{~mL}$ slurry in vacuo. The slurry was diluted with heptane (100 $\mathrm{mL})$ and 2-BuOH (4 mL) and heated to reflux to form a clear solution. Heptane (100 mL) was slowly added until cloudy solution formed. The suspension was slowly cooled to room temperature. The product was filtered off, washed with $3 \times 100 \mathrm{~mL}$ (30\% toluene in heptane) and dried under vacuum at $60{ }^{\circ} \mathrm{C}$ to give $56.9 \mathrm{~g}$ of white solid (89\% yield), $\mathrm{mp}$ 167-168 ${ }^{\circ} \mathrm{C} . \quad{ }^{1} \mathrm{H}$ NMR $\left(400 \mathrm{MHz}, \mathrm{CDCl}_{3}\right.$, mixture of rotamers) $\delta 7.35(\mathrm{~d}, 1 \mathrm{H}, J=8.4$ Hz), $7.26(\mathrm{~m}, 3 \mathrm{H}), 7.18(\mathrm{~m}, 1 \mathrm{H}), 7.05(\mathrm{~d}, 1 \mathrm{H}, J=8.4 \mathrm{~Hz}), 6.90(\mathrm{br}, 1 \mathrm{H}), 6.88$ and 6.73 (m, $0.85 \mathrm{H}$ and $0.15 \mathrm{H}), 6.33$ and $5.91(\mathrm{br}, 0.85 \mathrm{H}$ and $0.15 \mathrm{H}), 4.12$ and $4.04(\mathrm{~m}, 0.15 \mathrm{H}$ and $0.85 \mathrm{H}), 2.72(\mathrm{~m}, 1 \mathrm{H}), 2.61(\mathrm{~m}, 1 \mathrm{H}), 2.18$ and $1.95(\mathrm{~s}, 2.6 \mathrm{H}$ and $0.4 \mathrm{H}) .{ }^{13} \mathrm{C}$ NMR (100 $\left.\mathrm{MHz} \mathrm{CDCl}_{3}\right) \quad \delta 169.2,143.8,137.7,131.8,131.4,130.5,130.4,130.3,130.2,128.2$, 127.8, 127.2, 121.2, 117.4, 42.6, 30.4, 24.1. HRMS $(\mathrm{m} / \mathrm{z})\left[\mathrm{M}+\mathrm{H}^{+}\right]$calcd for $\mathrm{C}_{18} \mathrm{H}_{15} \mathrm{Cl}_{2} \mathrm{NO}$ 332.0609; found, 332.0624 . 

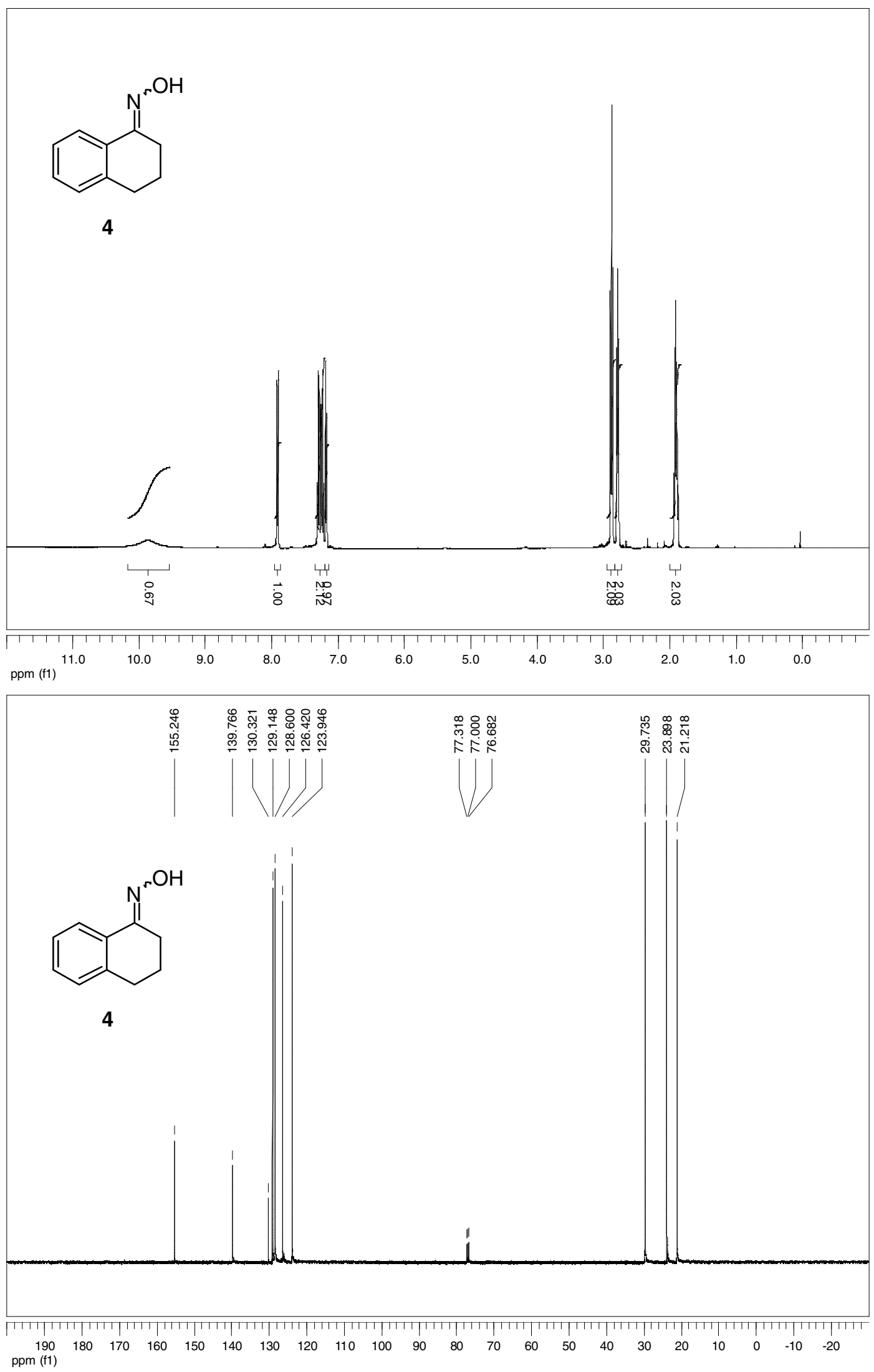

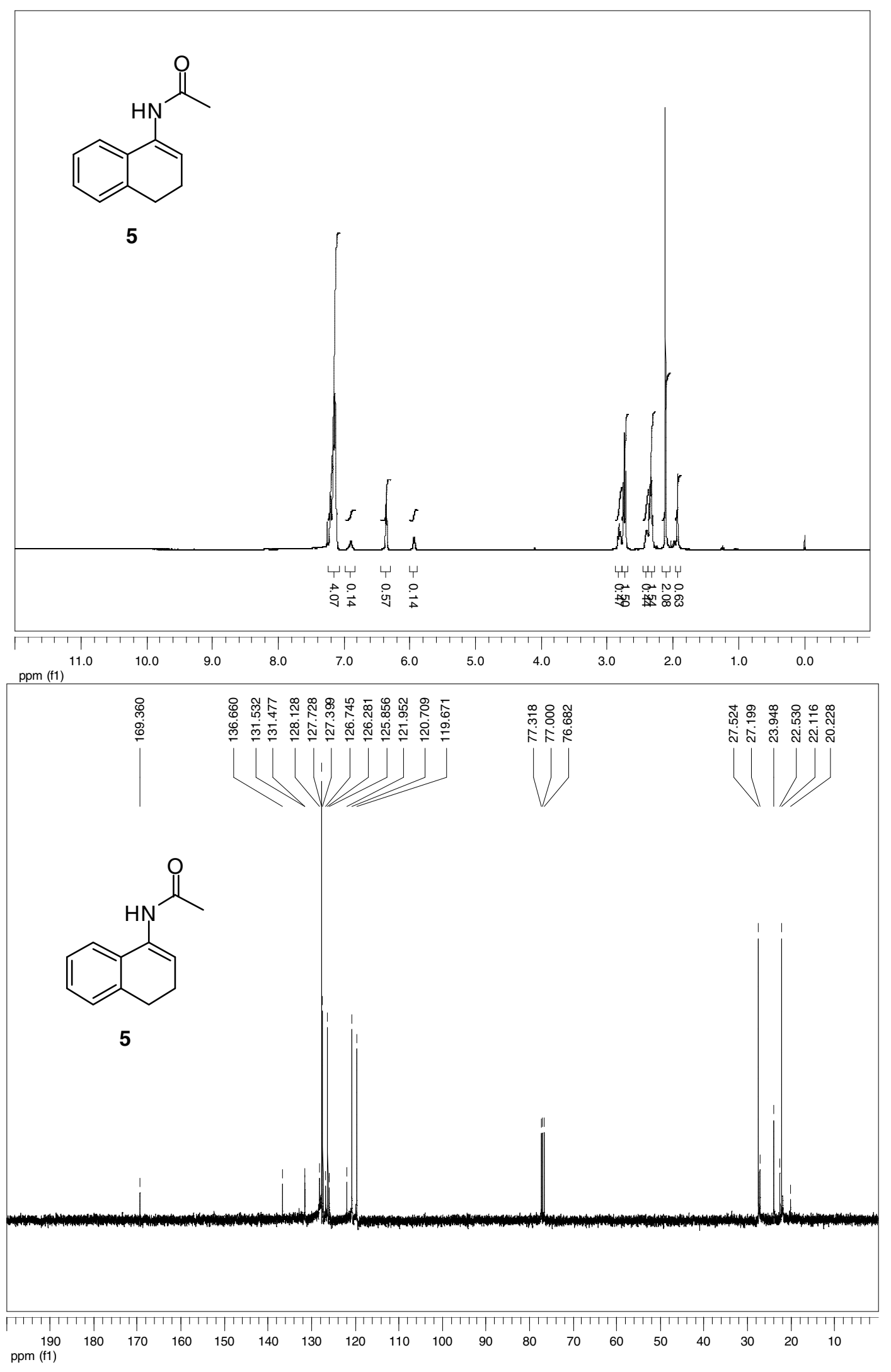

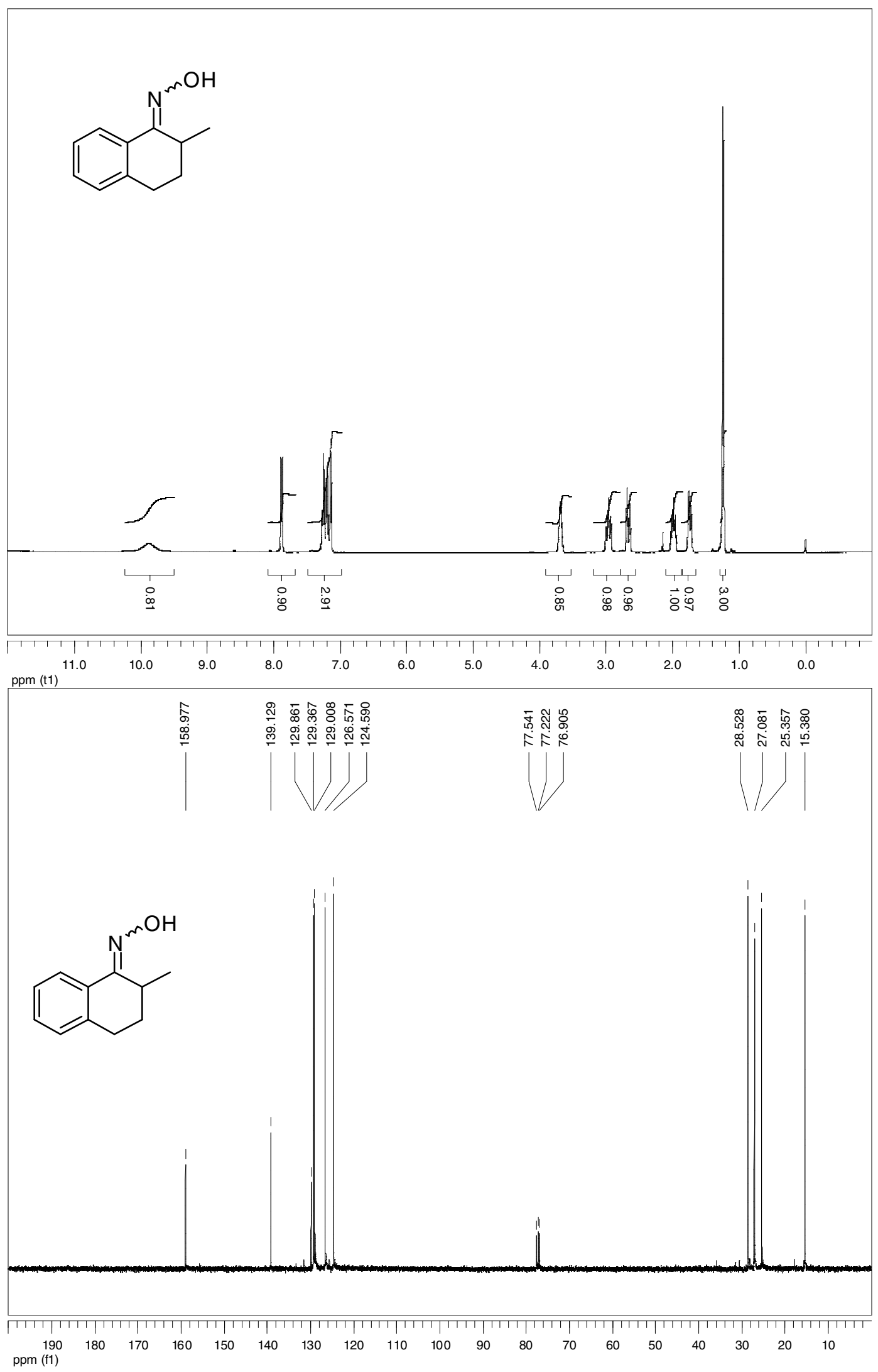

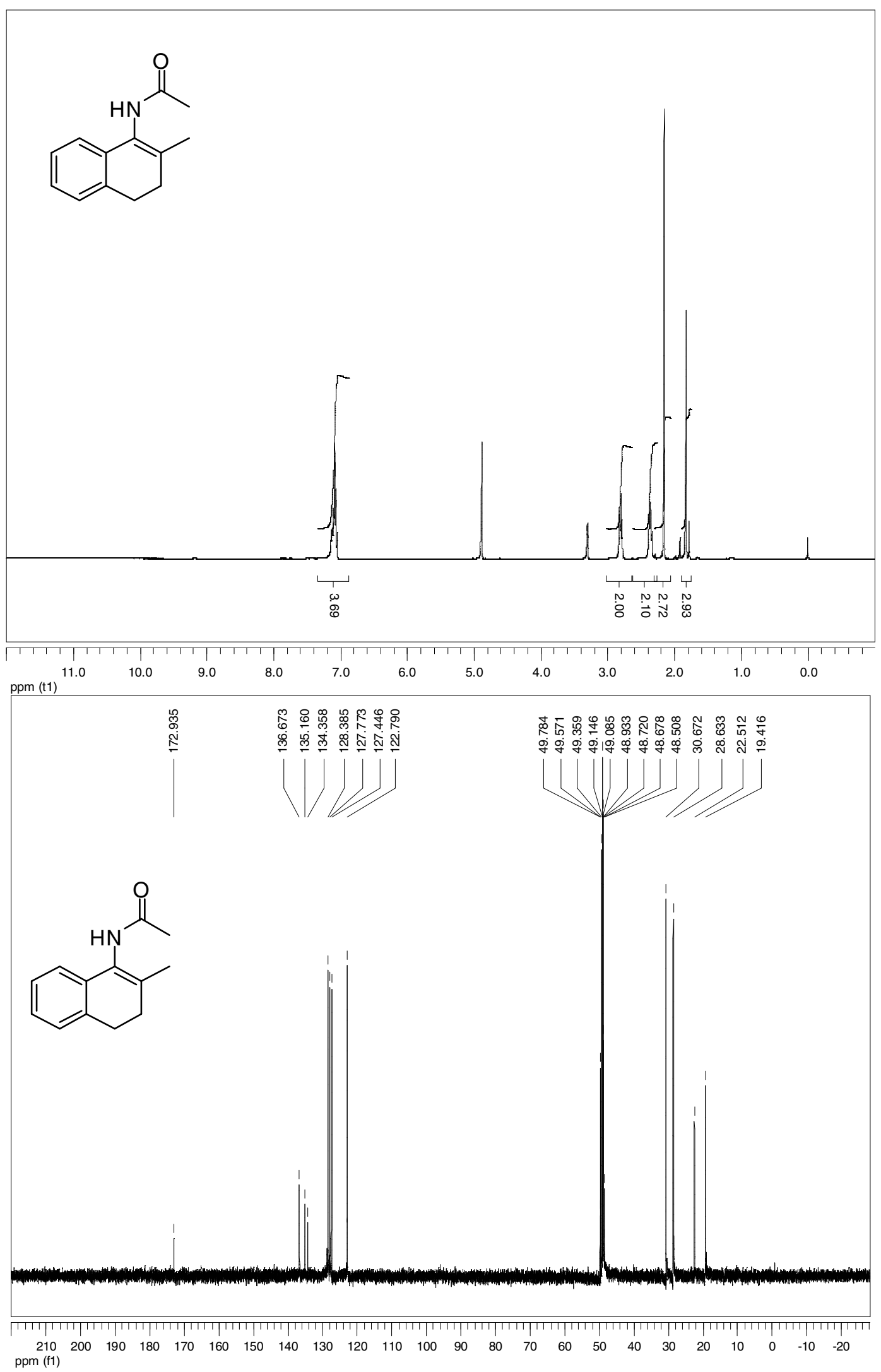

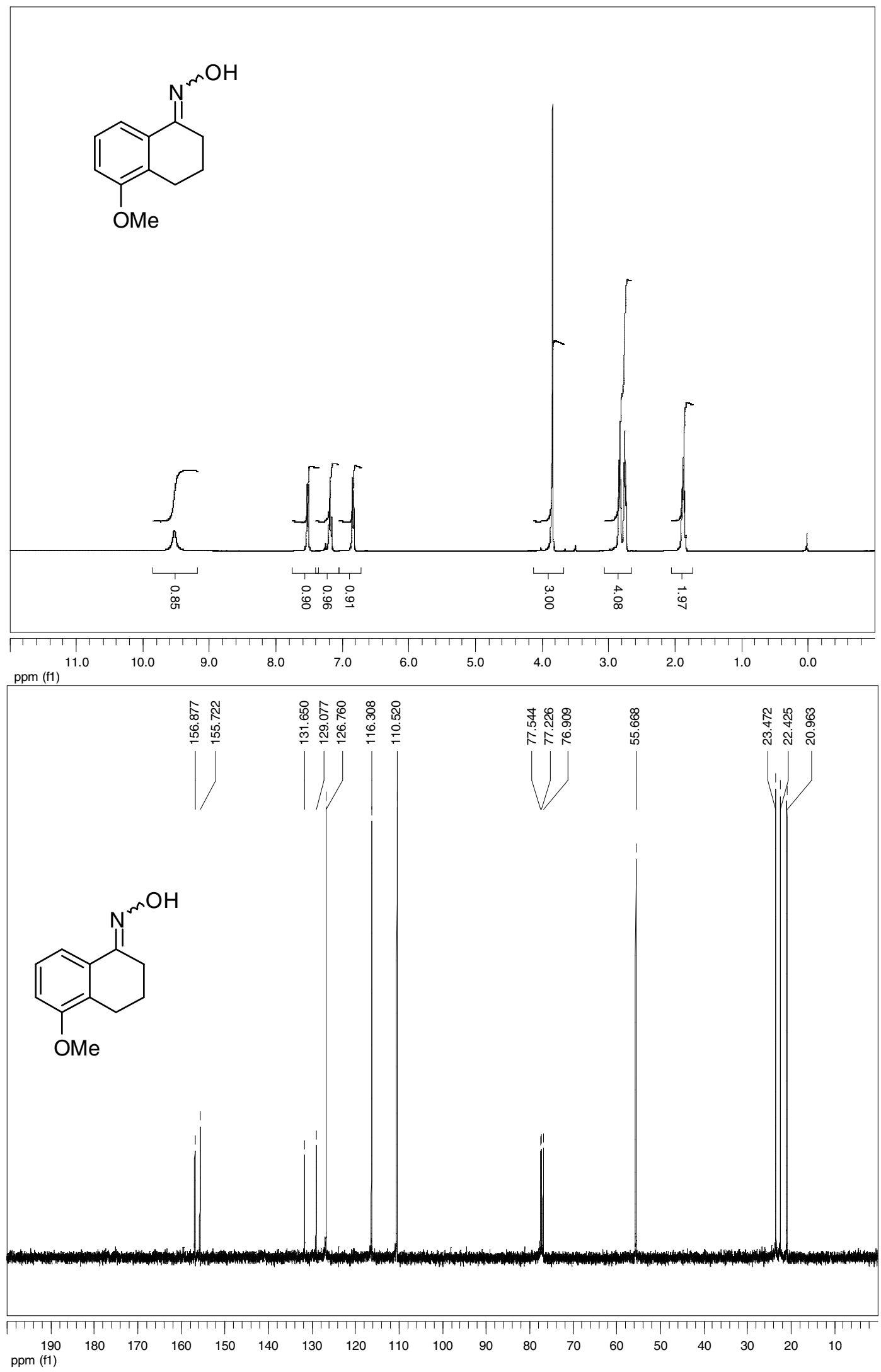

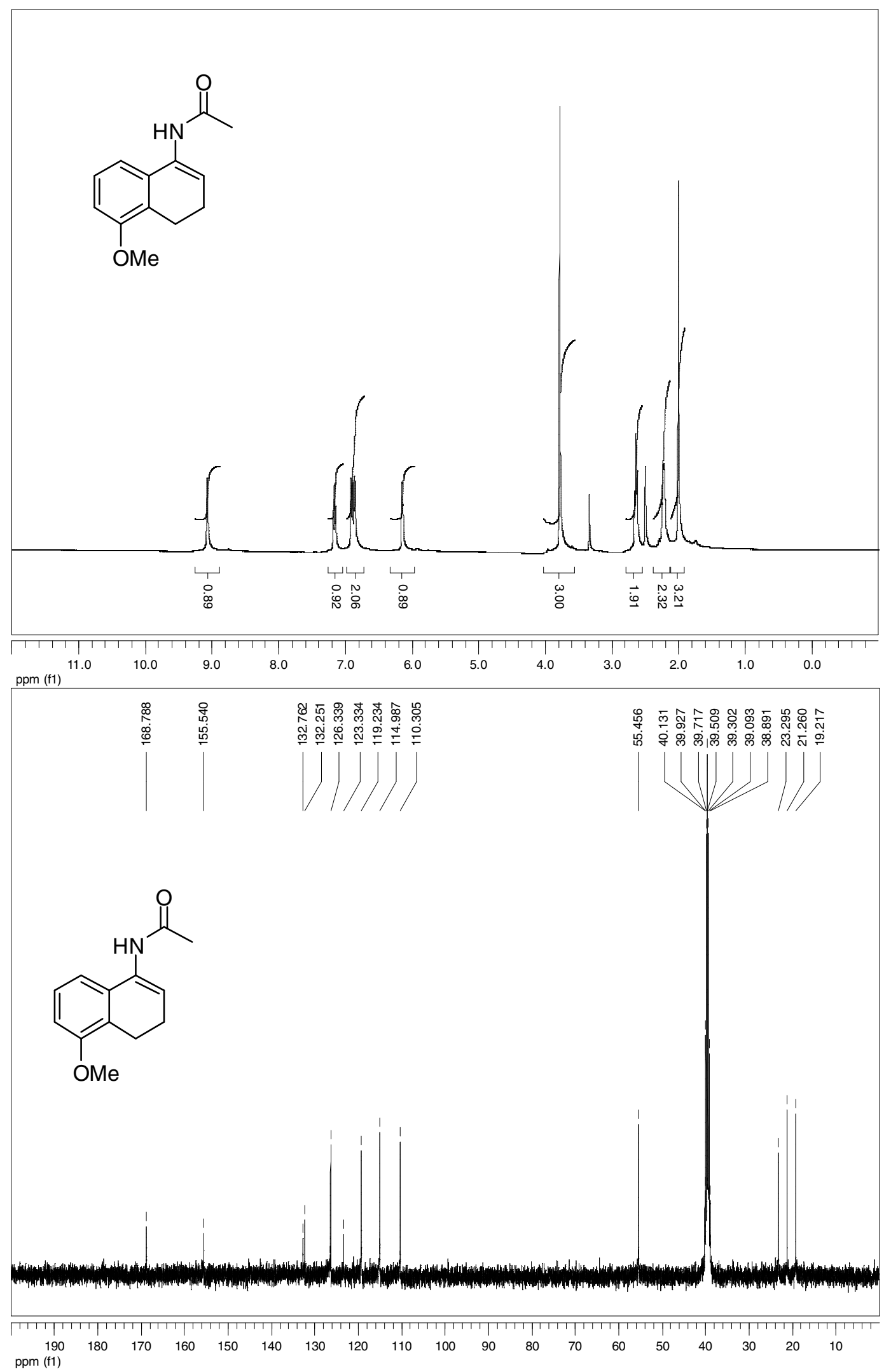

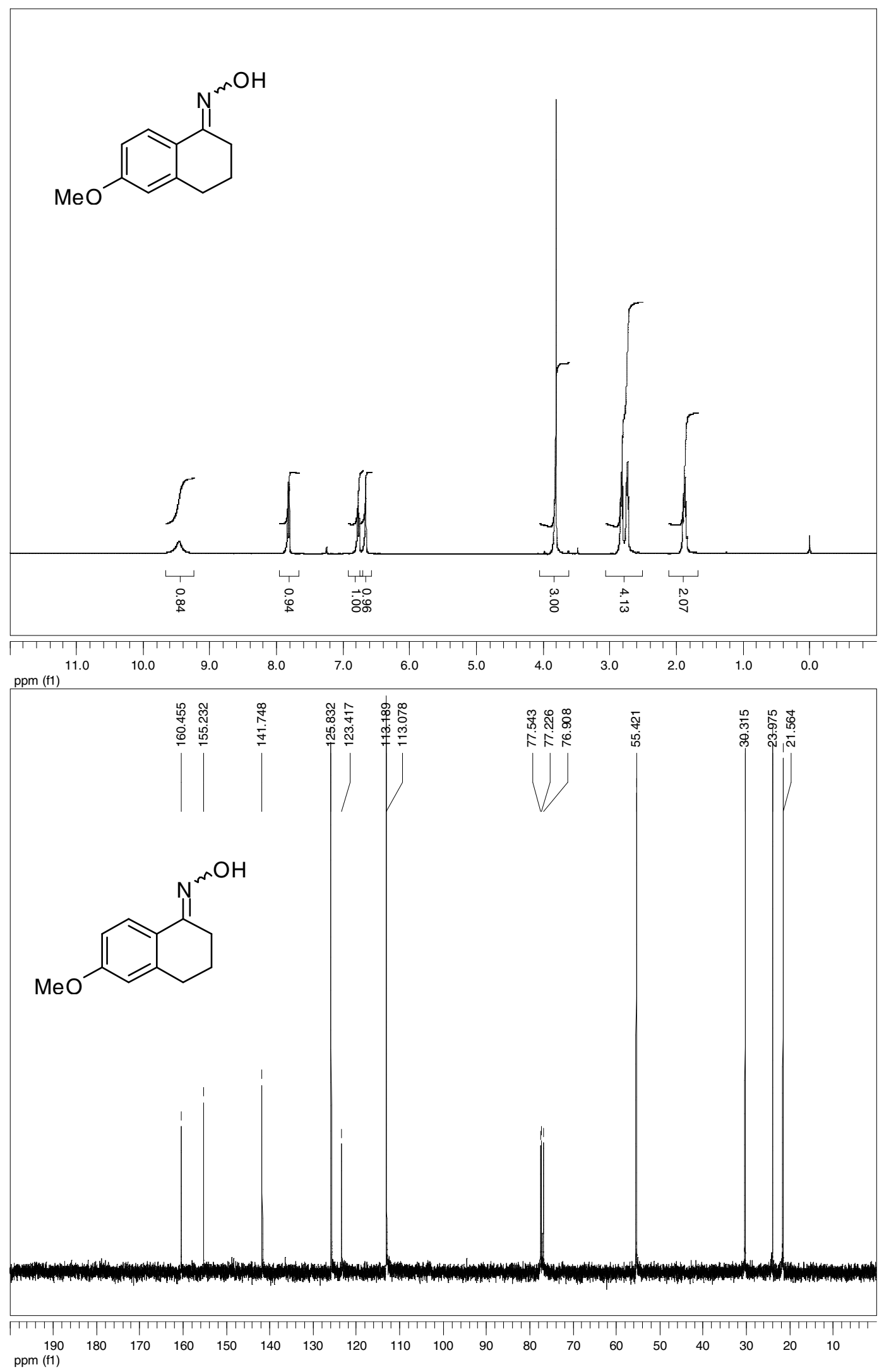

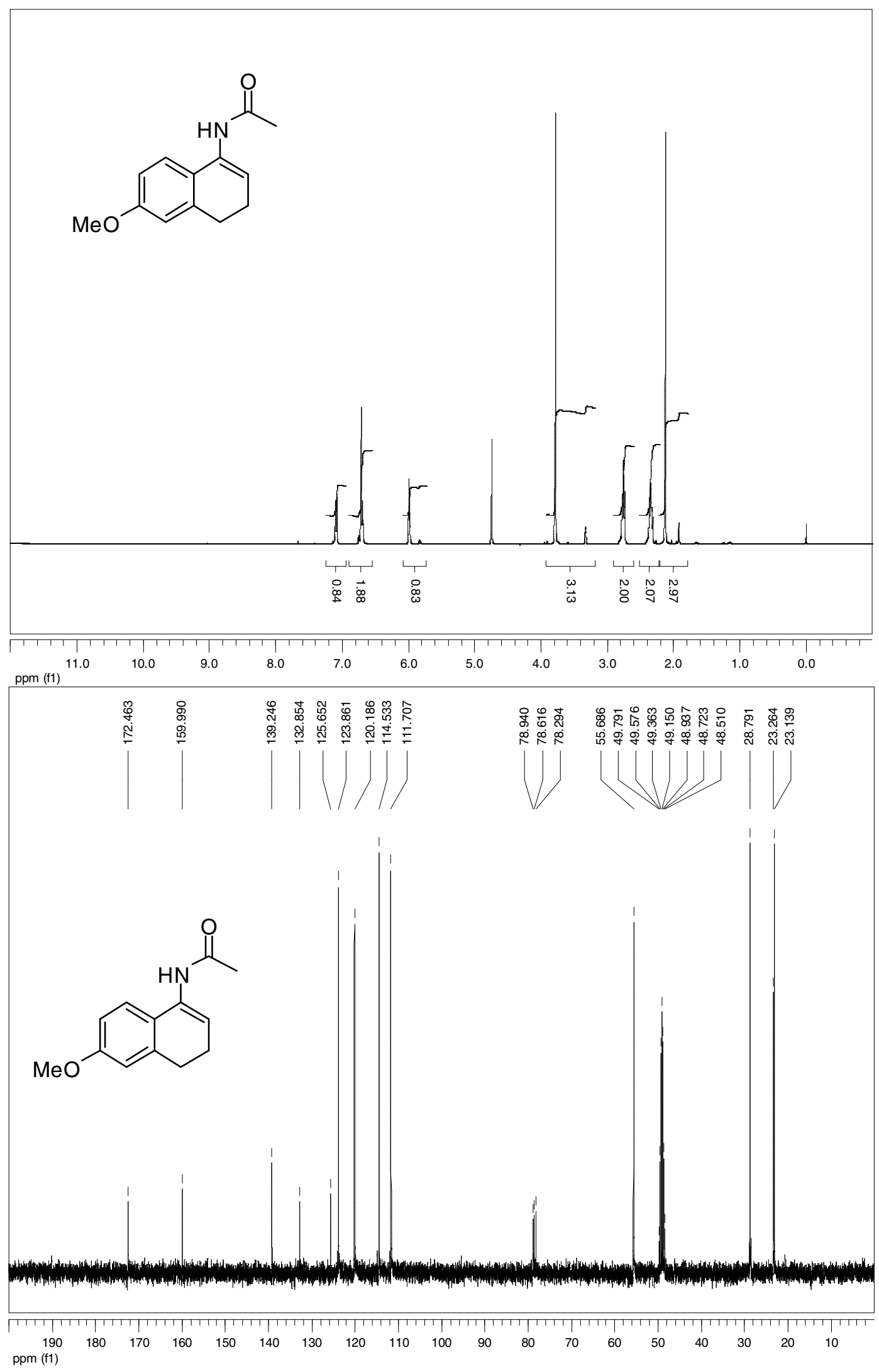

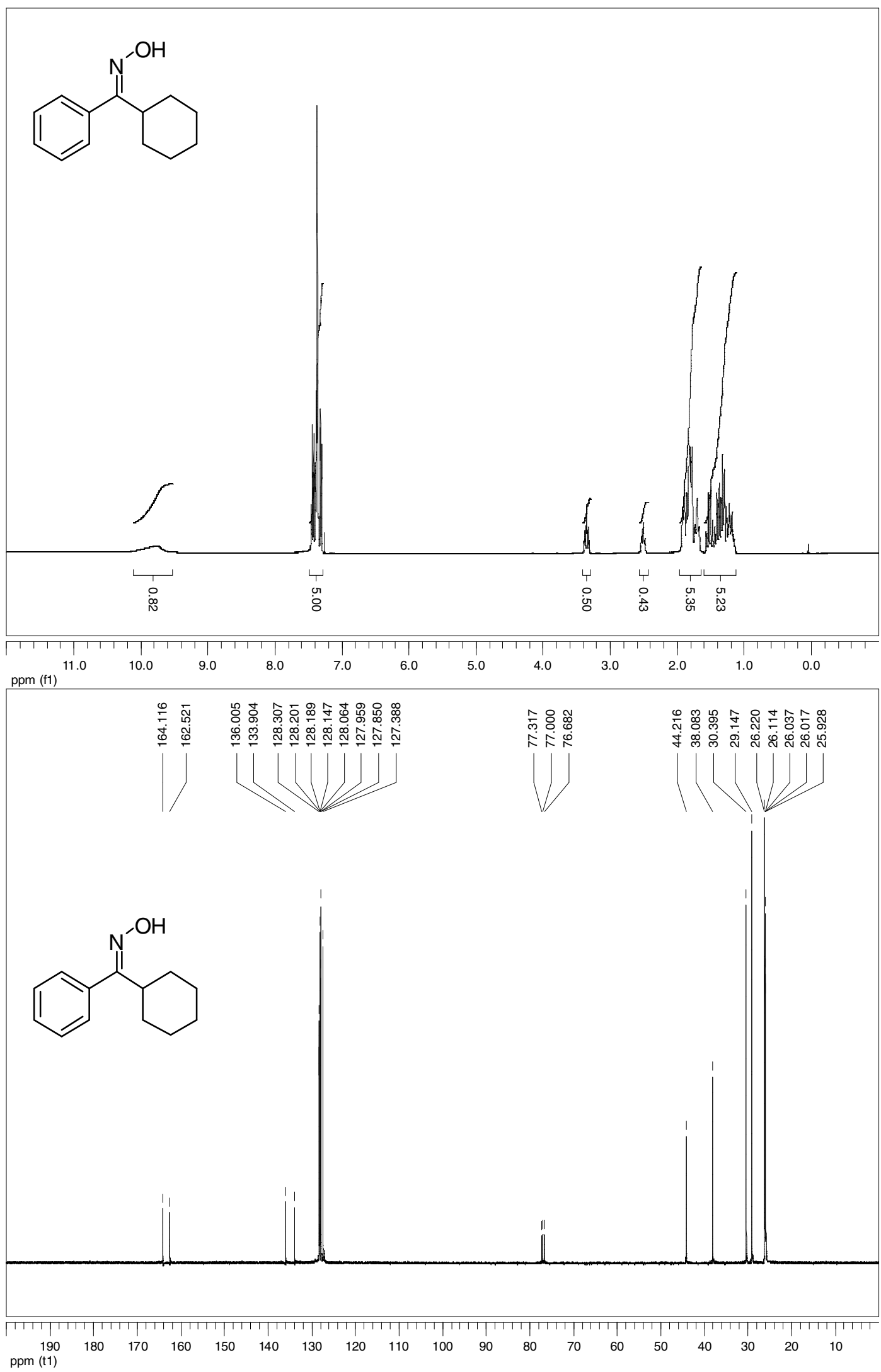

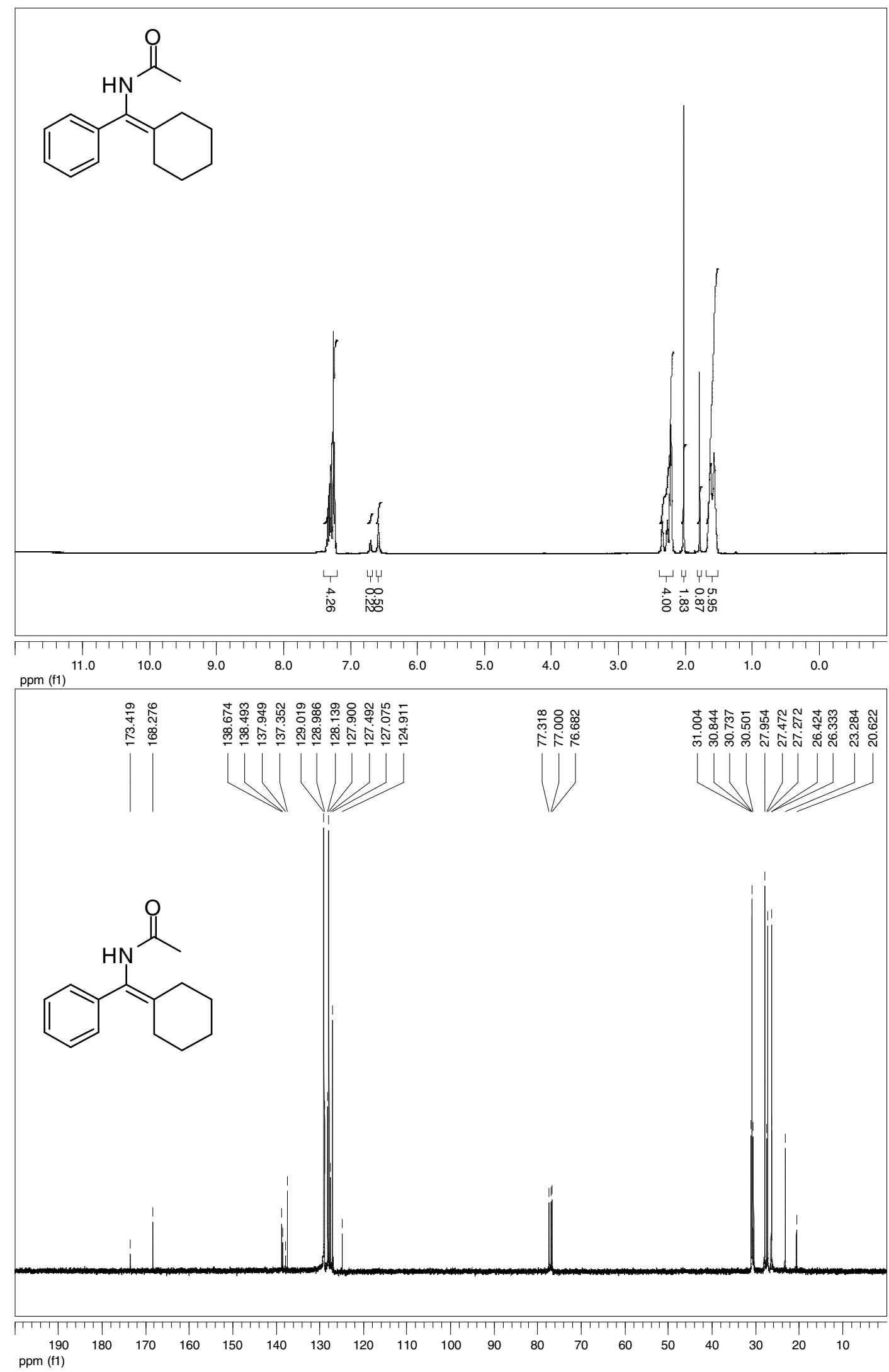

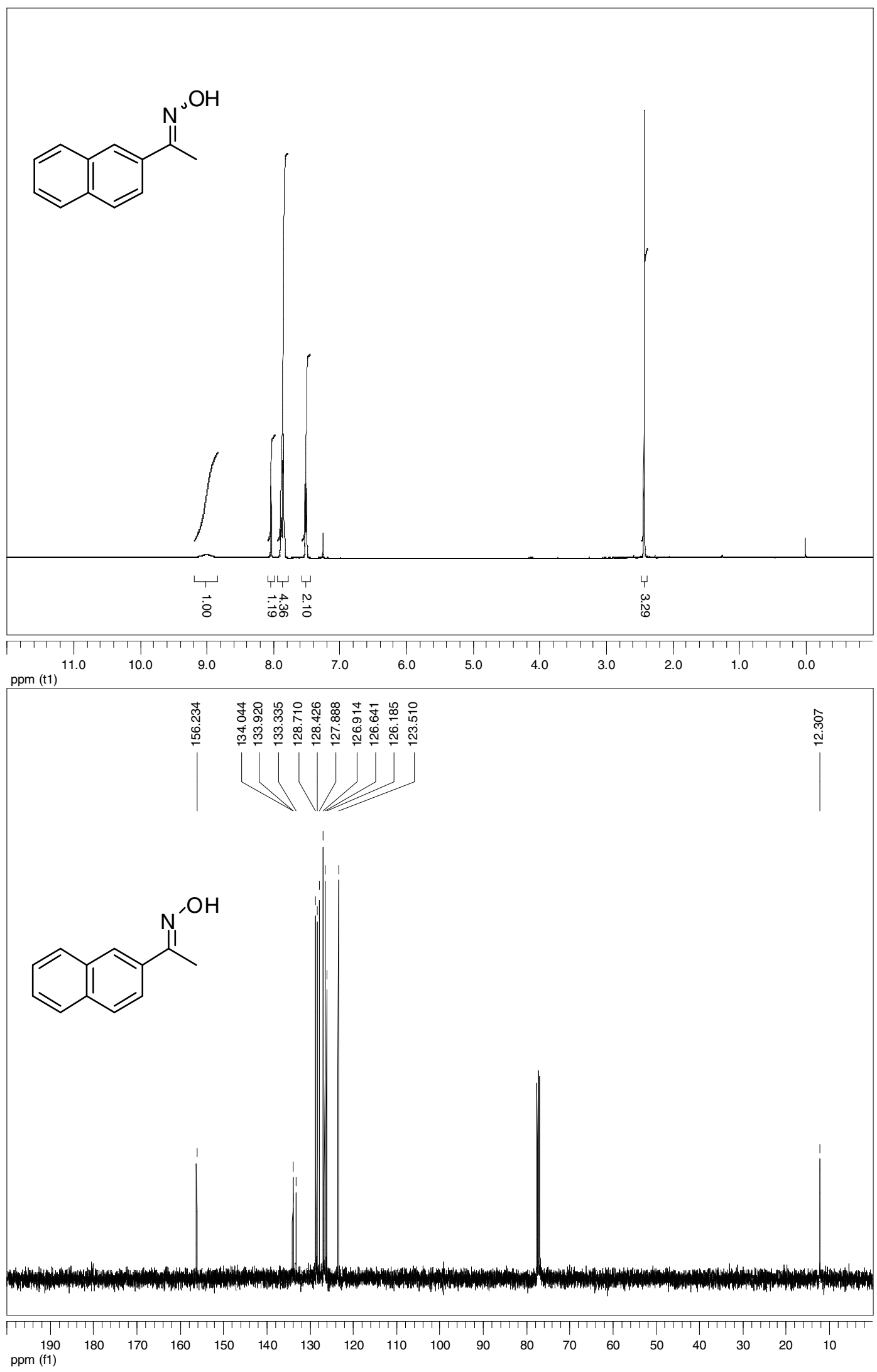

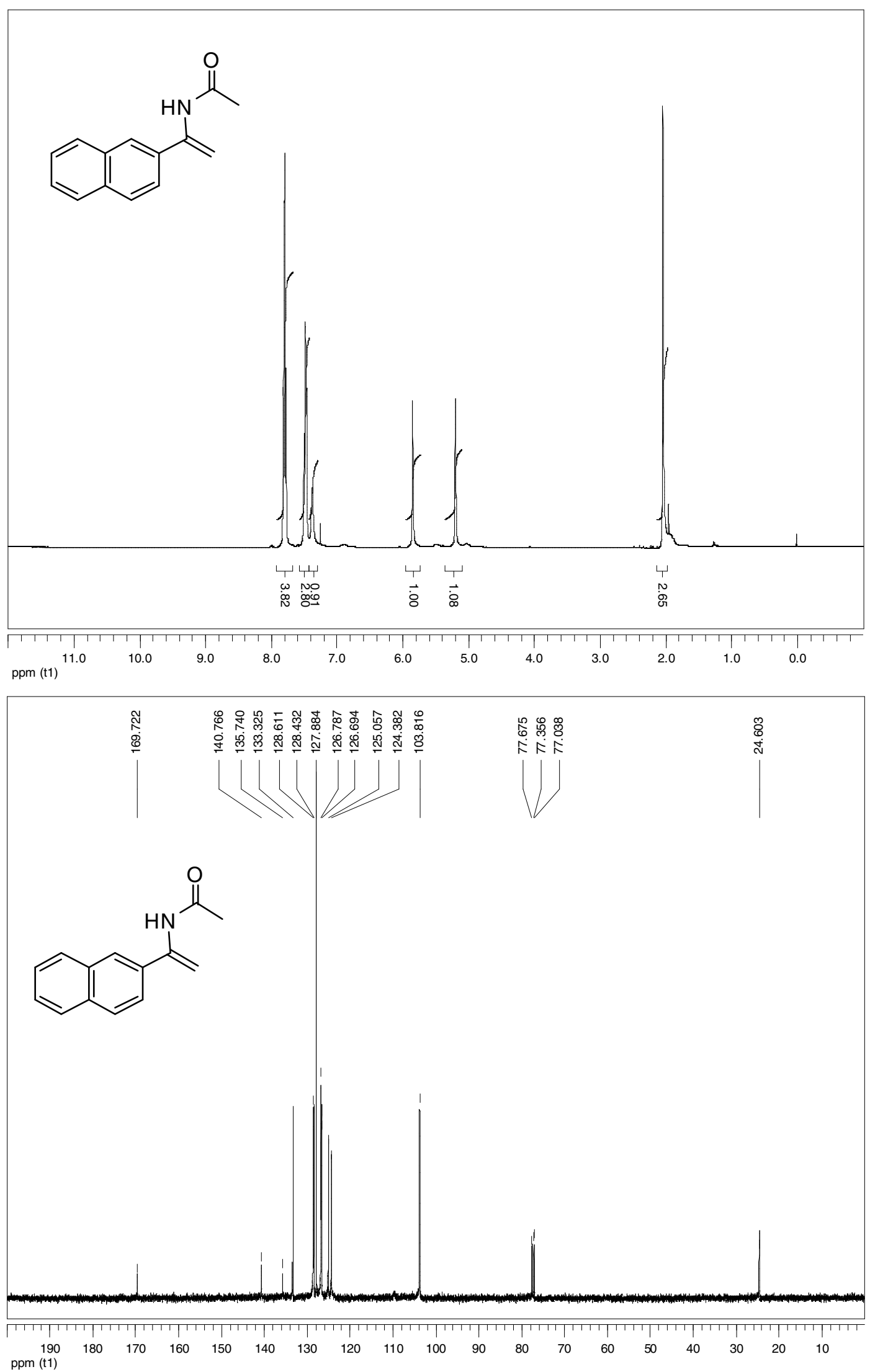


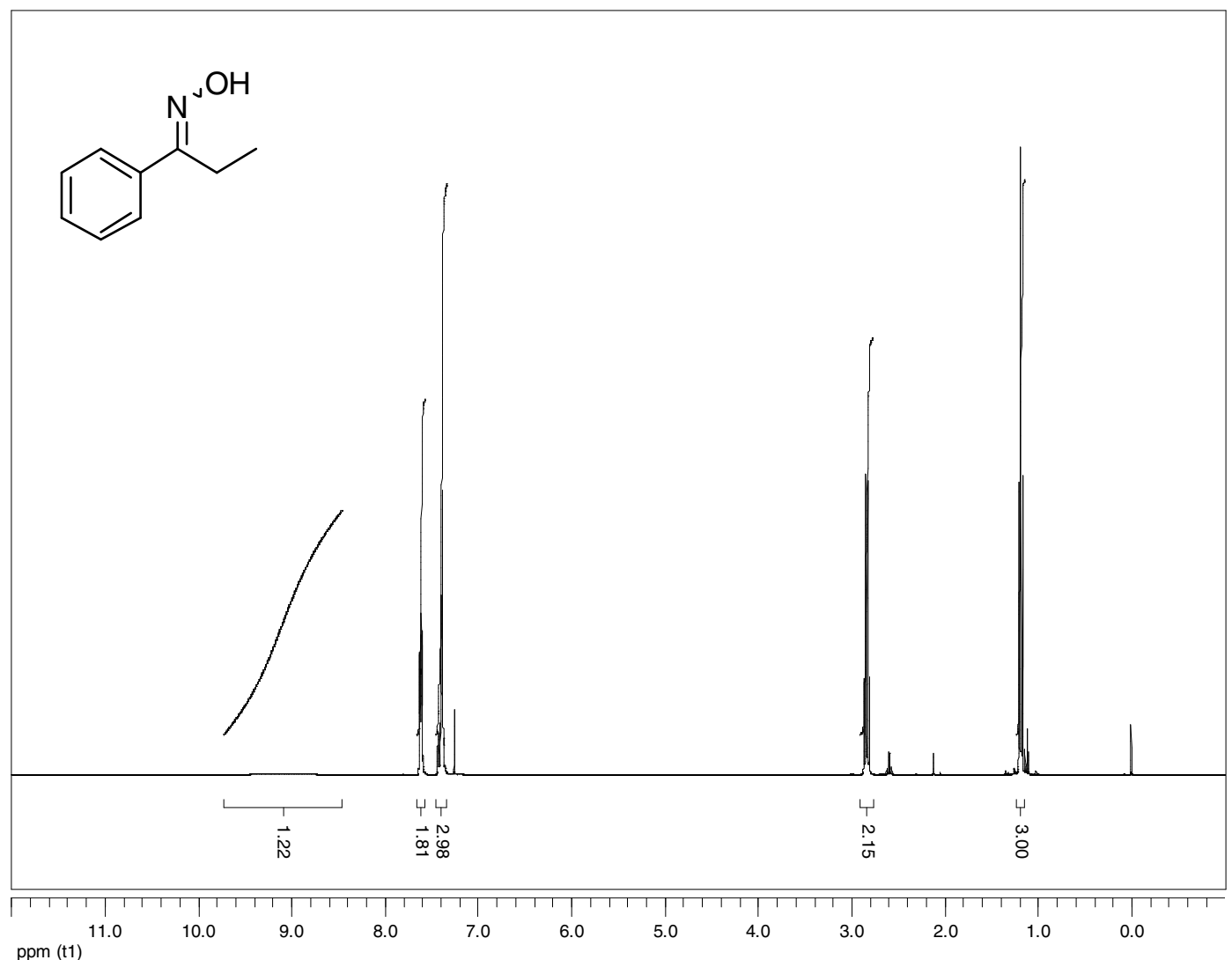
ppm (t1)

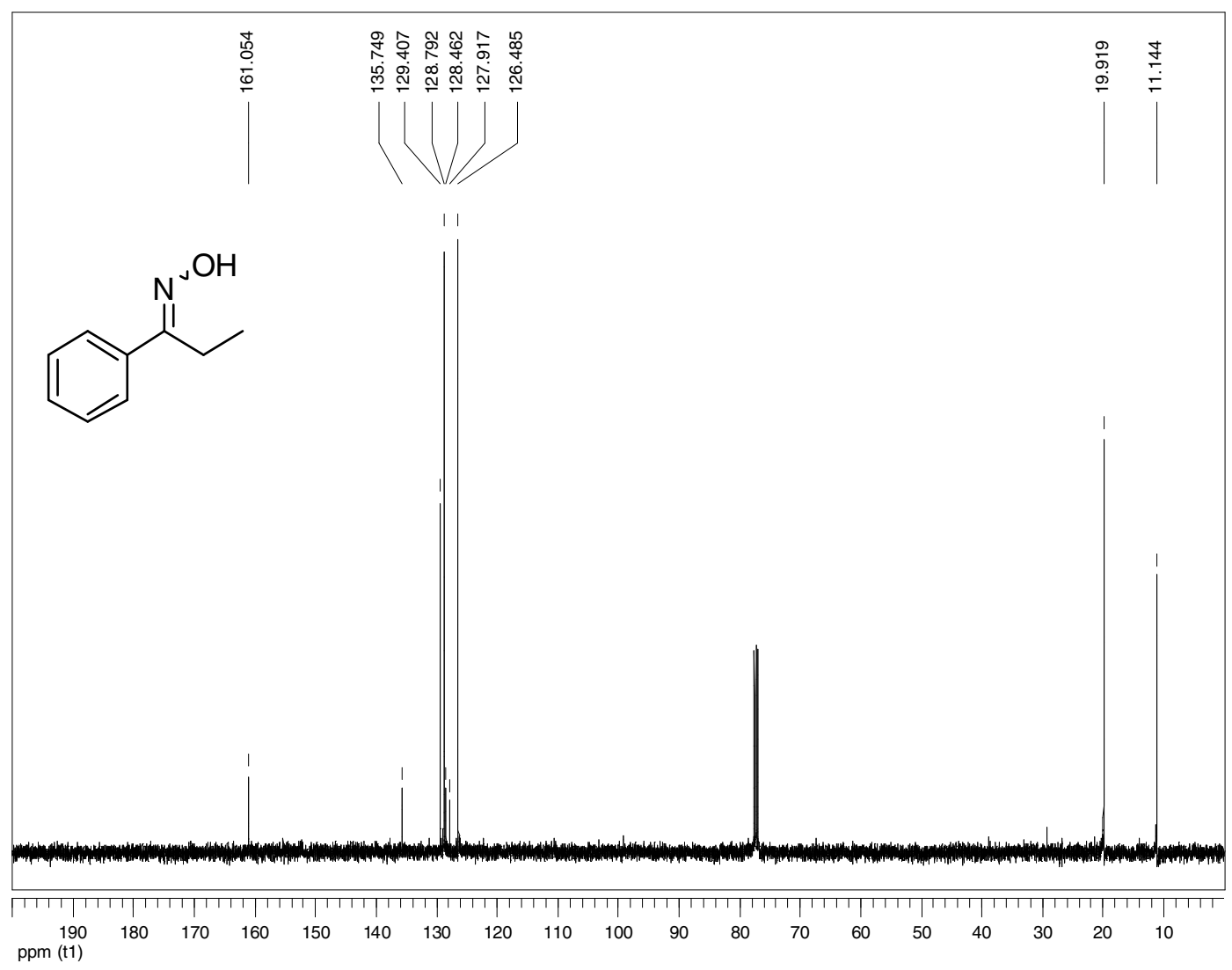




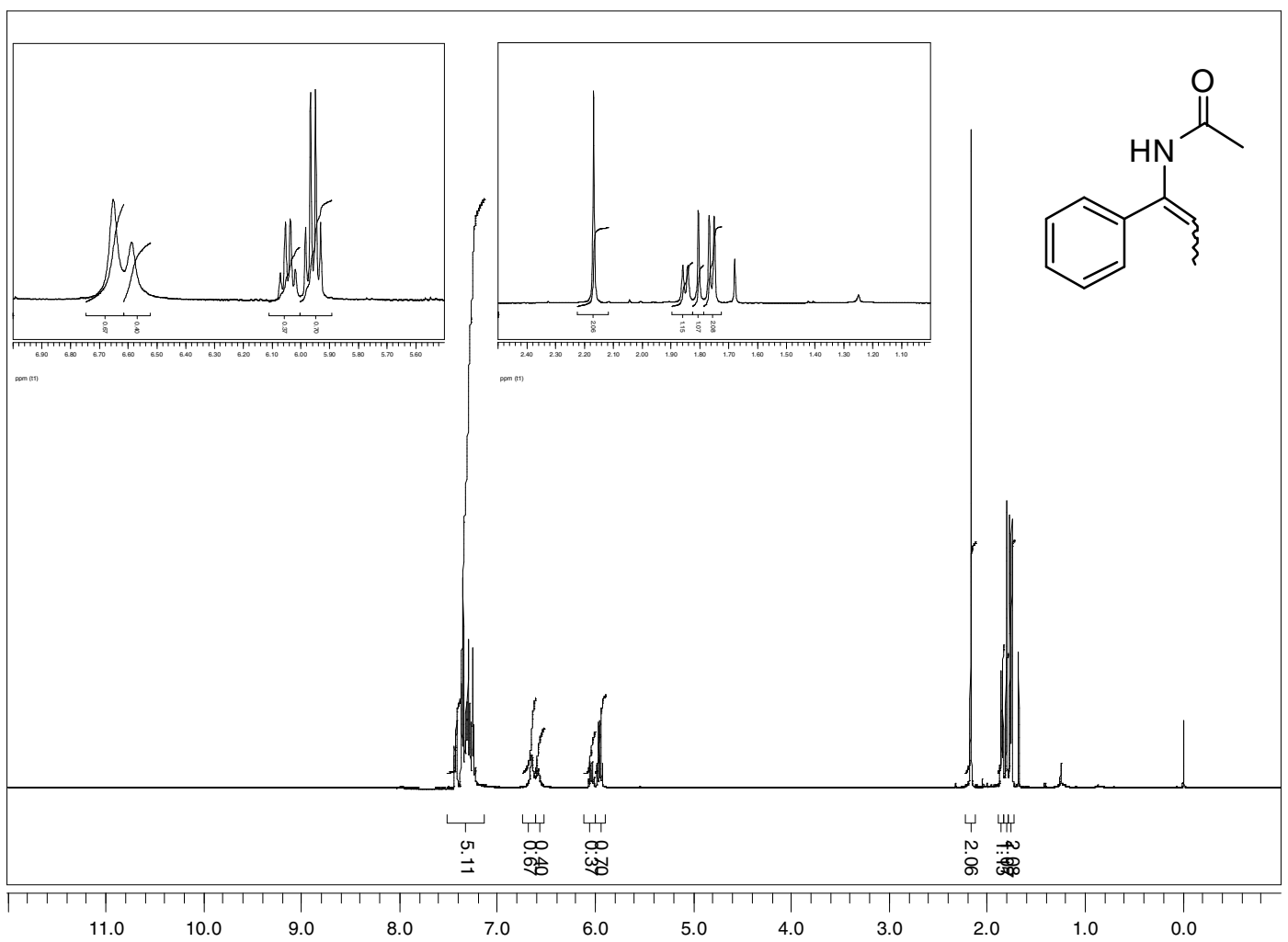

ppm (t1)

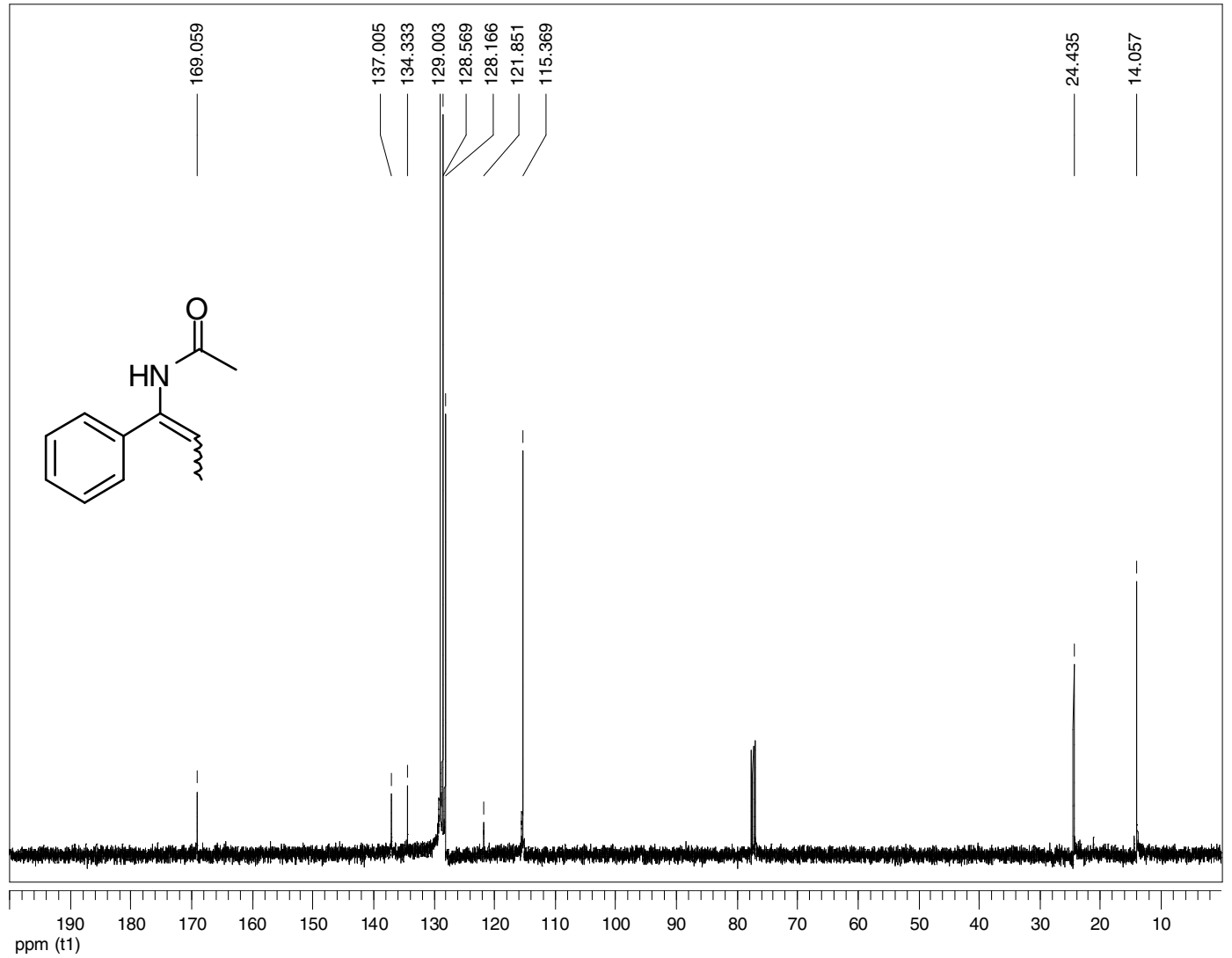



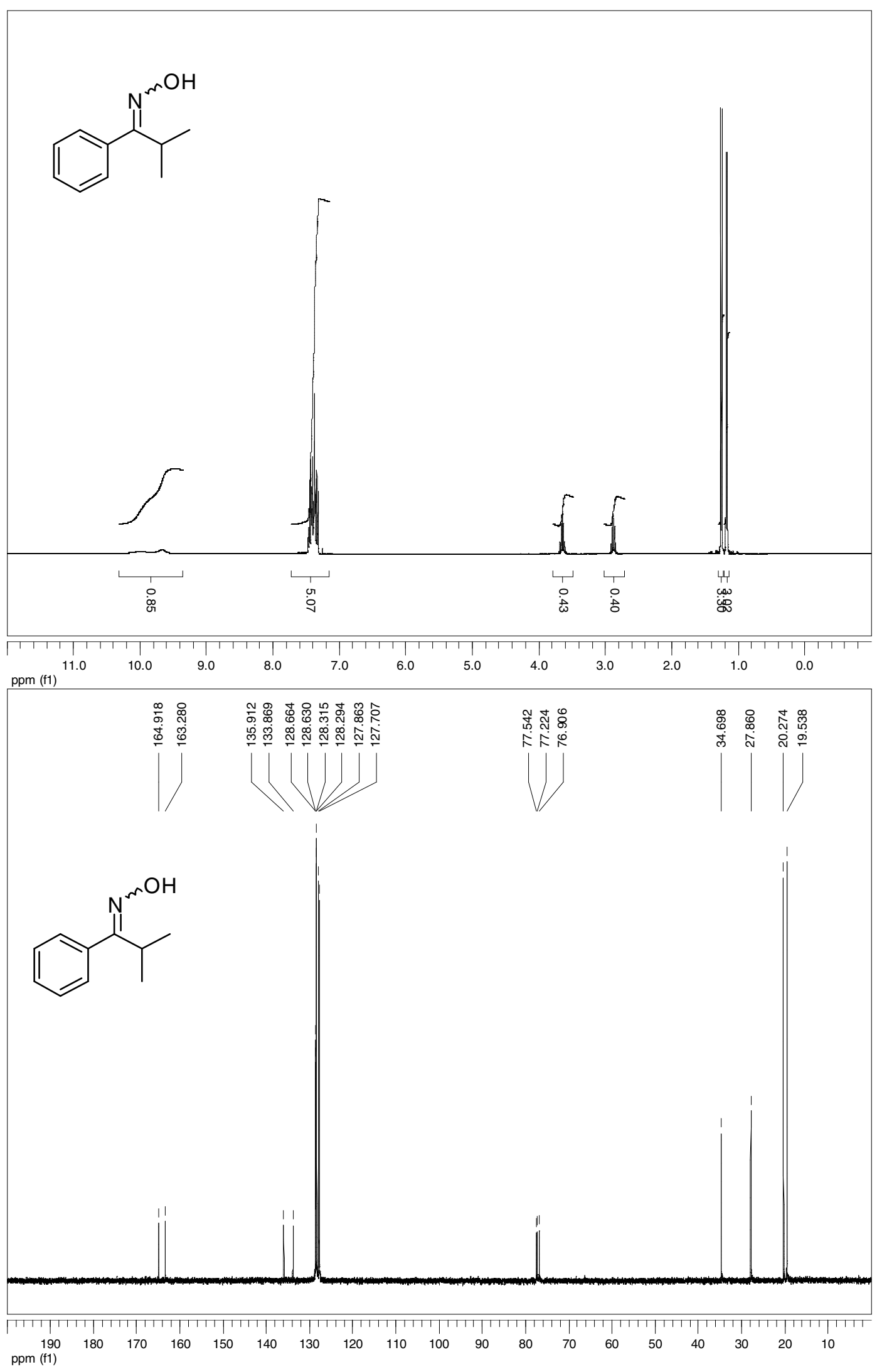

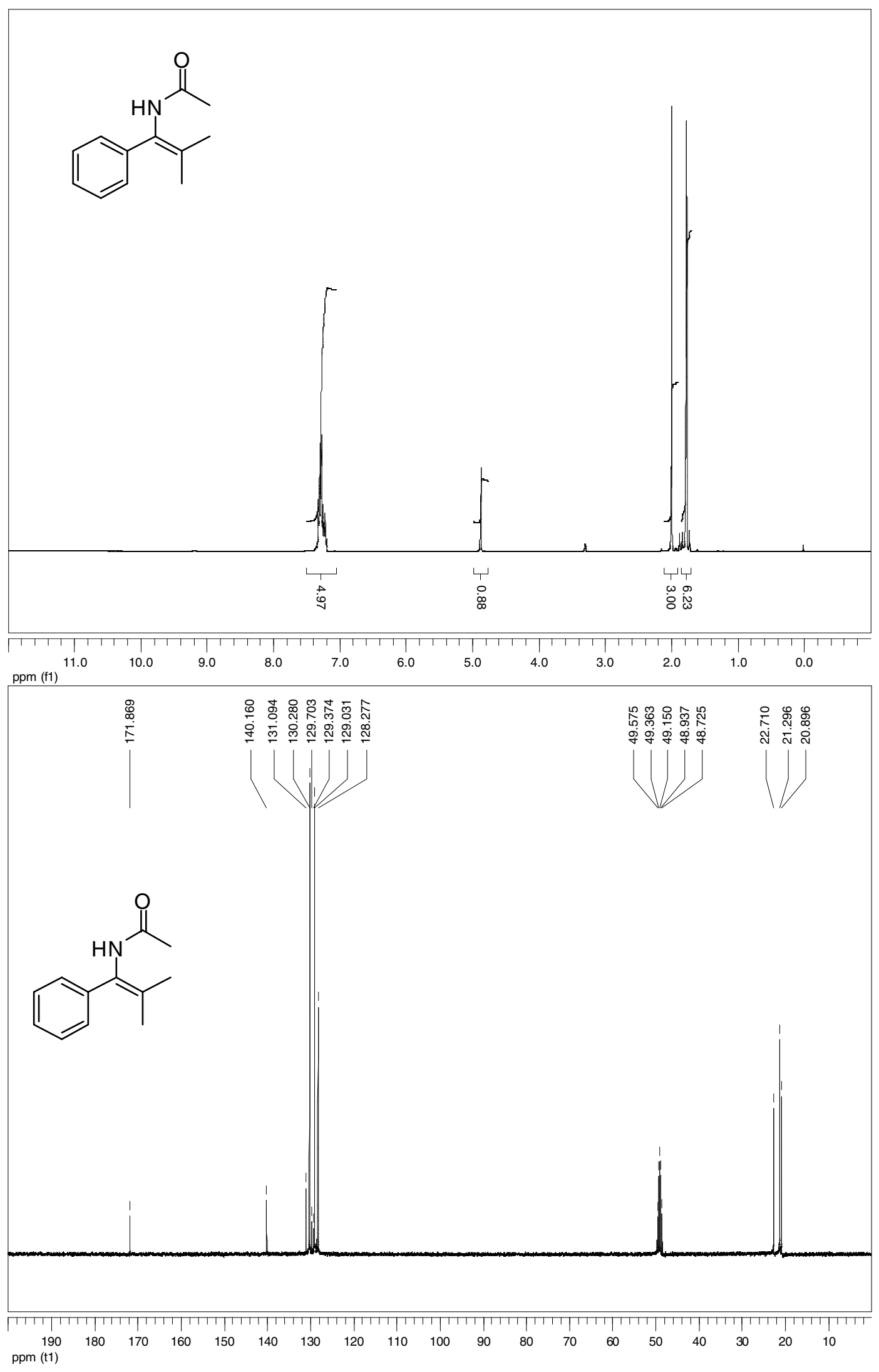


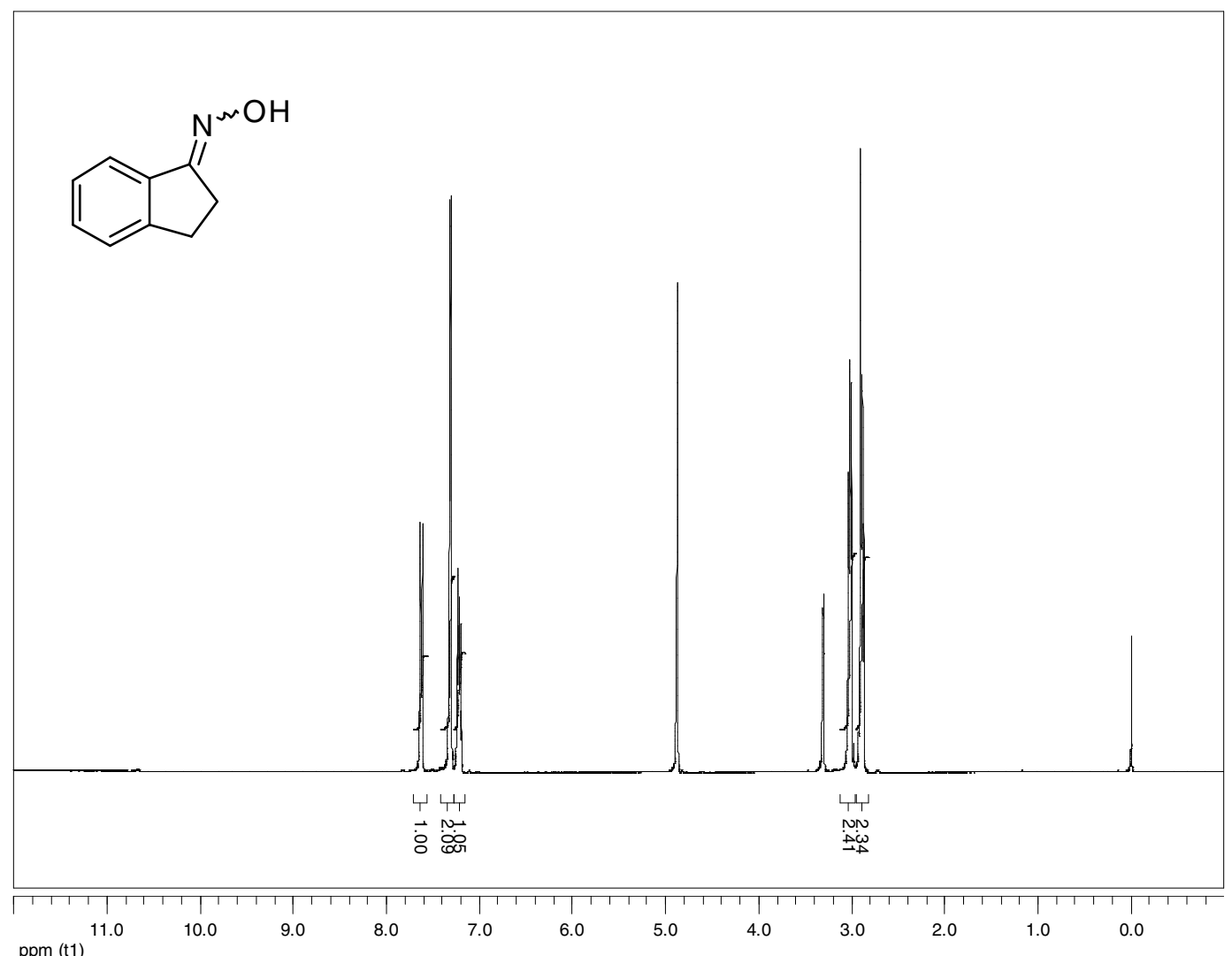

ppm (t1)

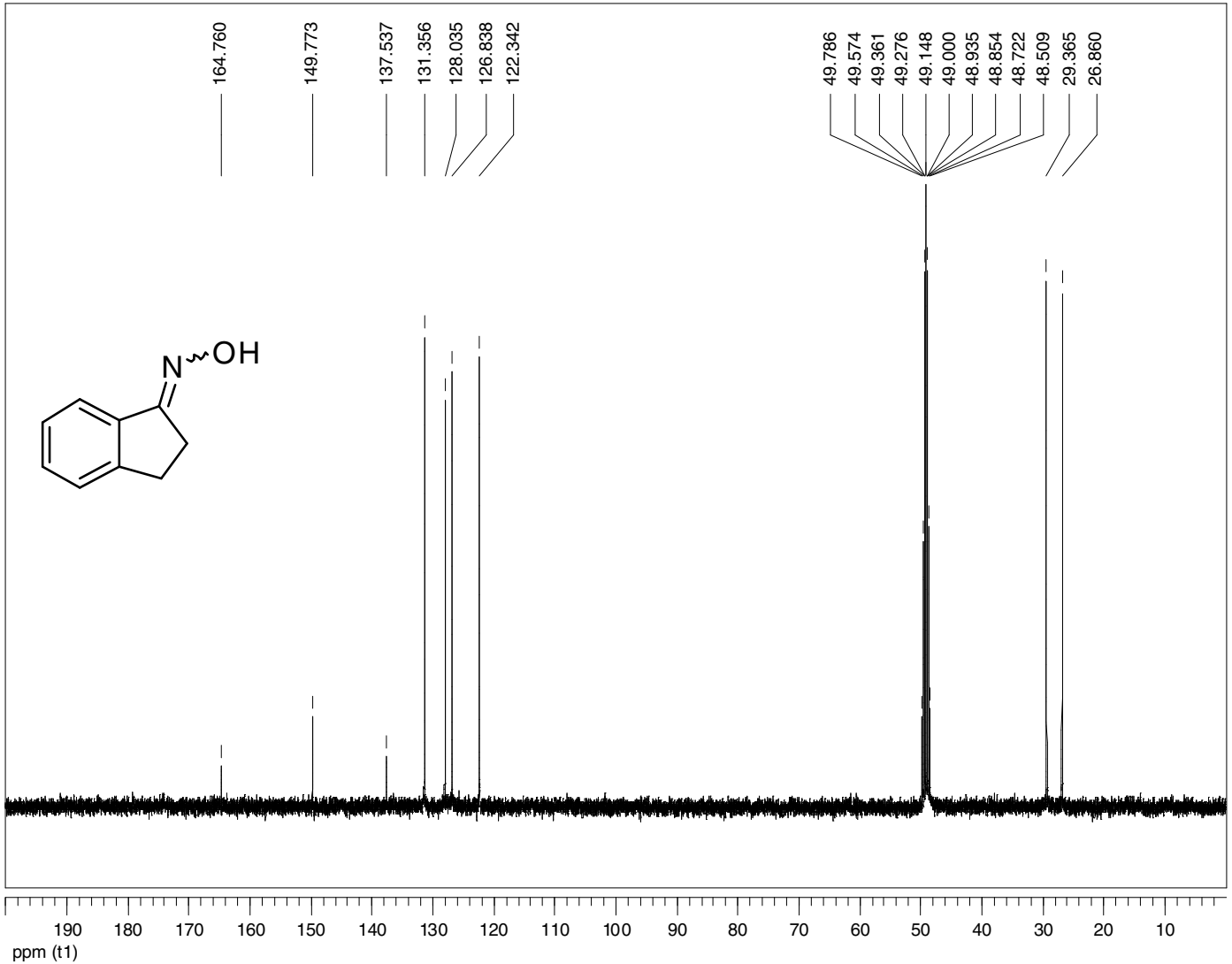



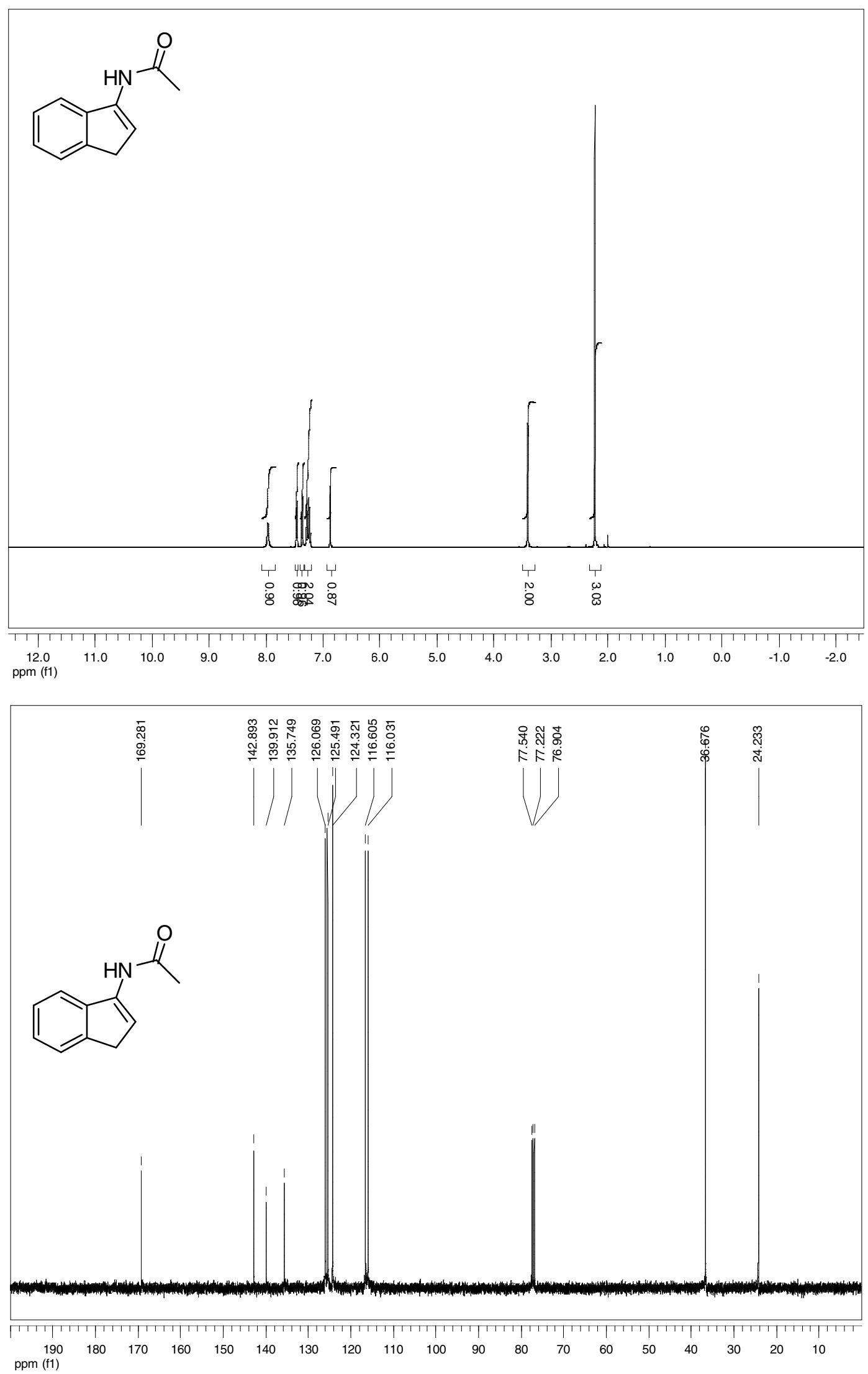

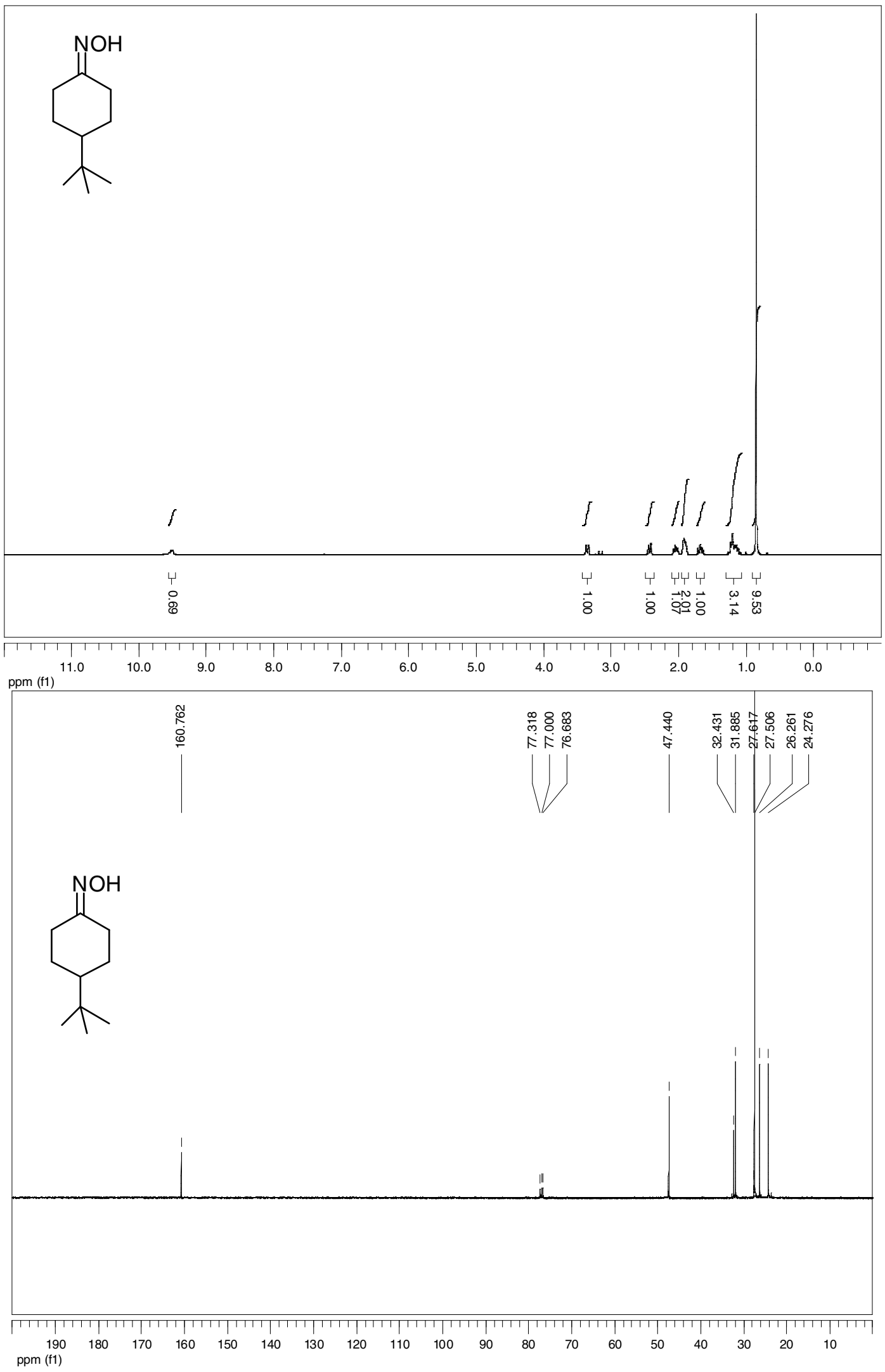

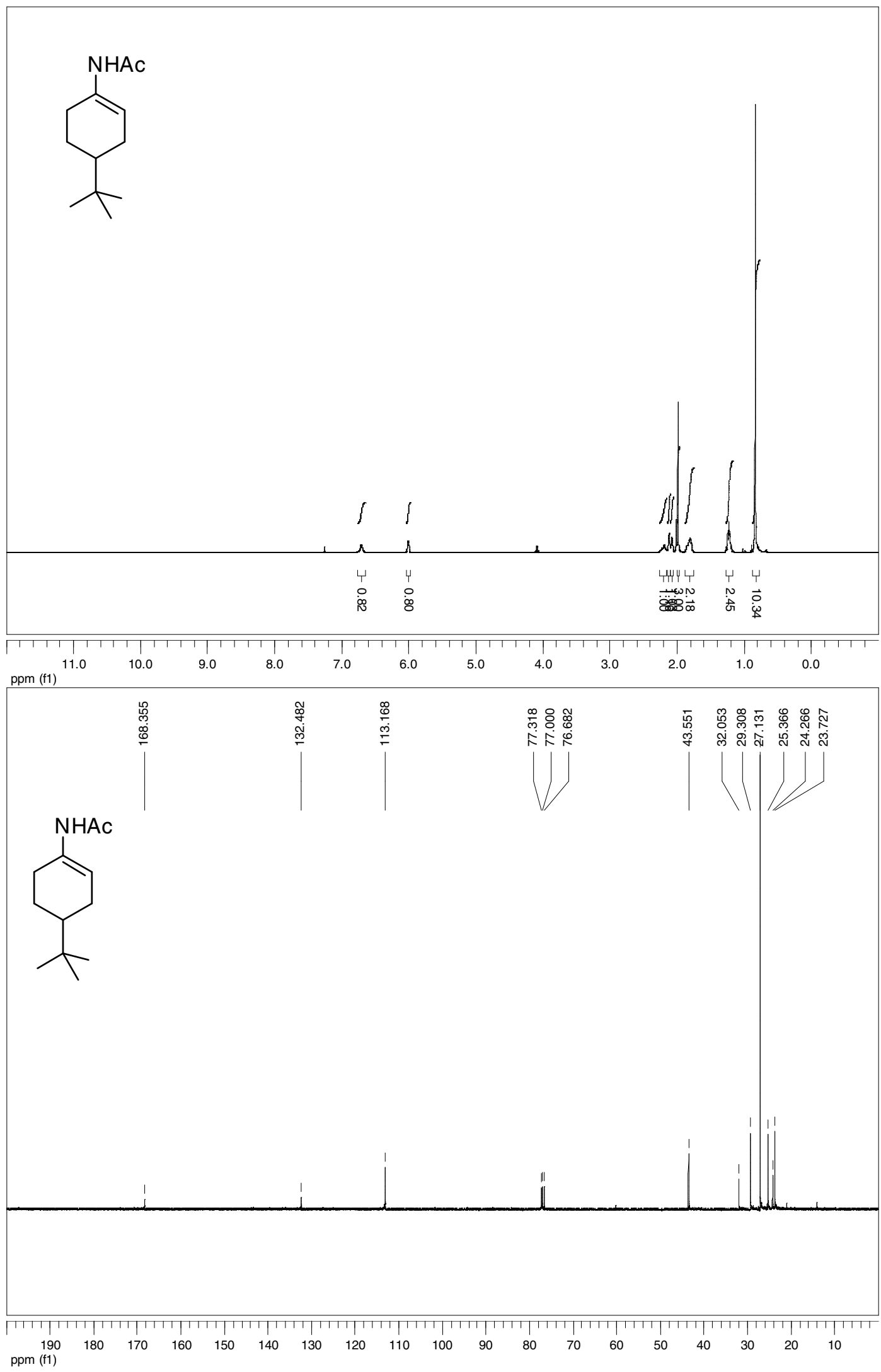

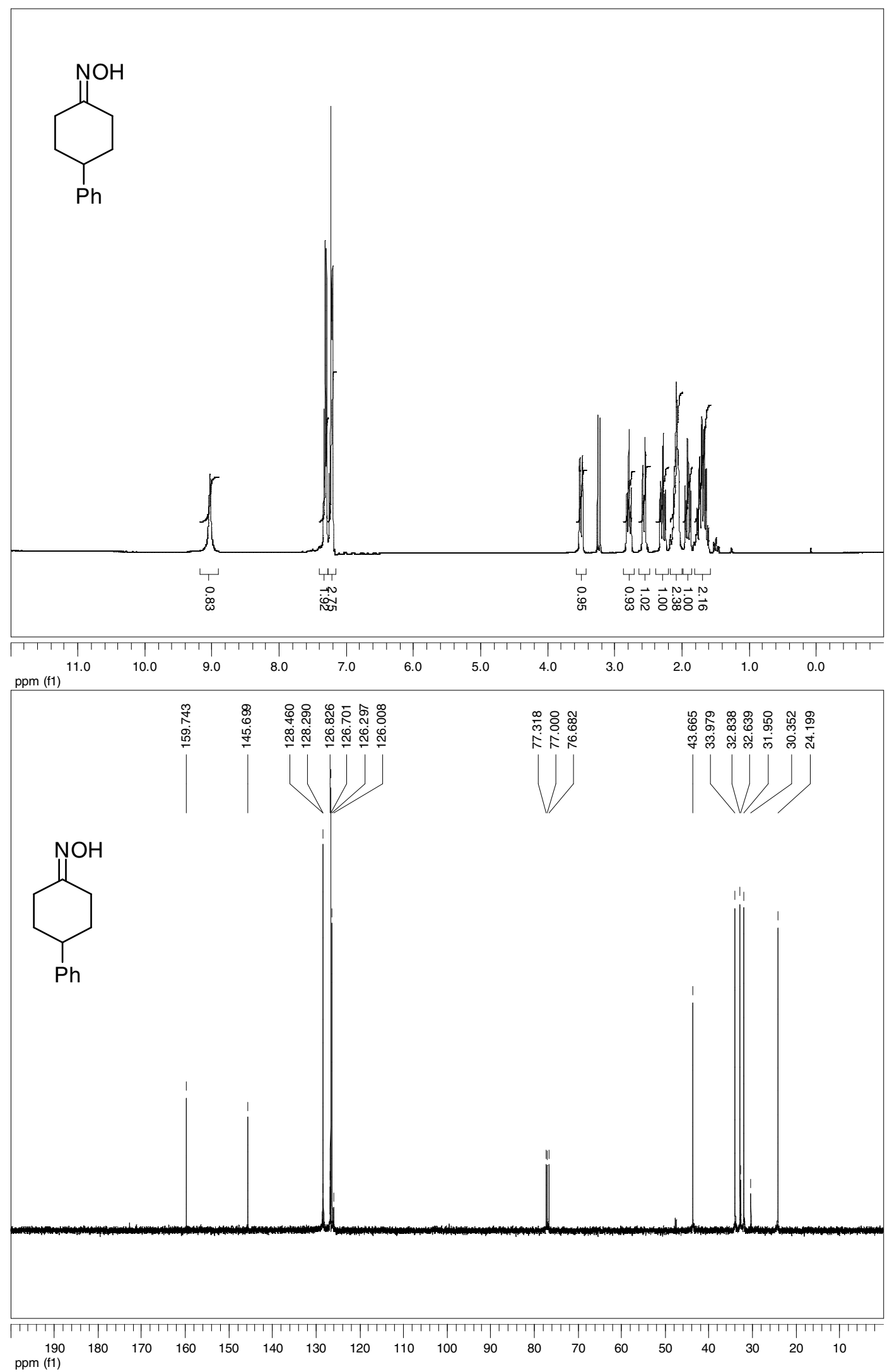

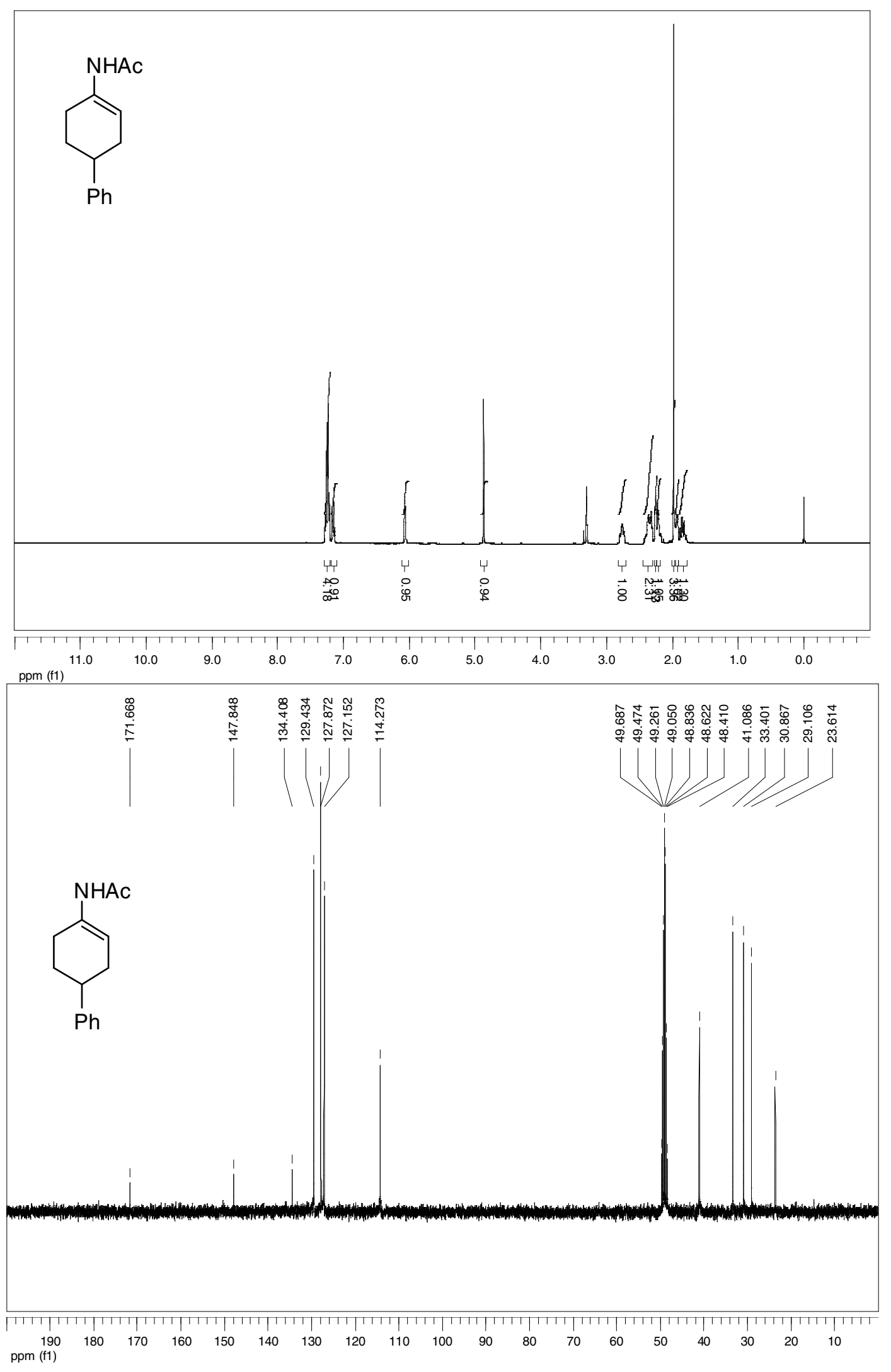

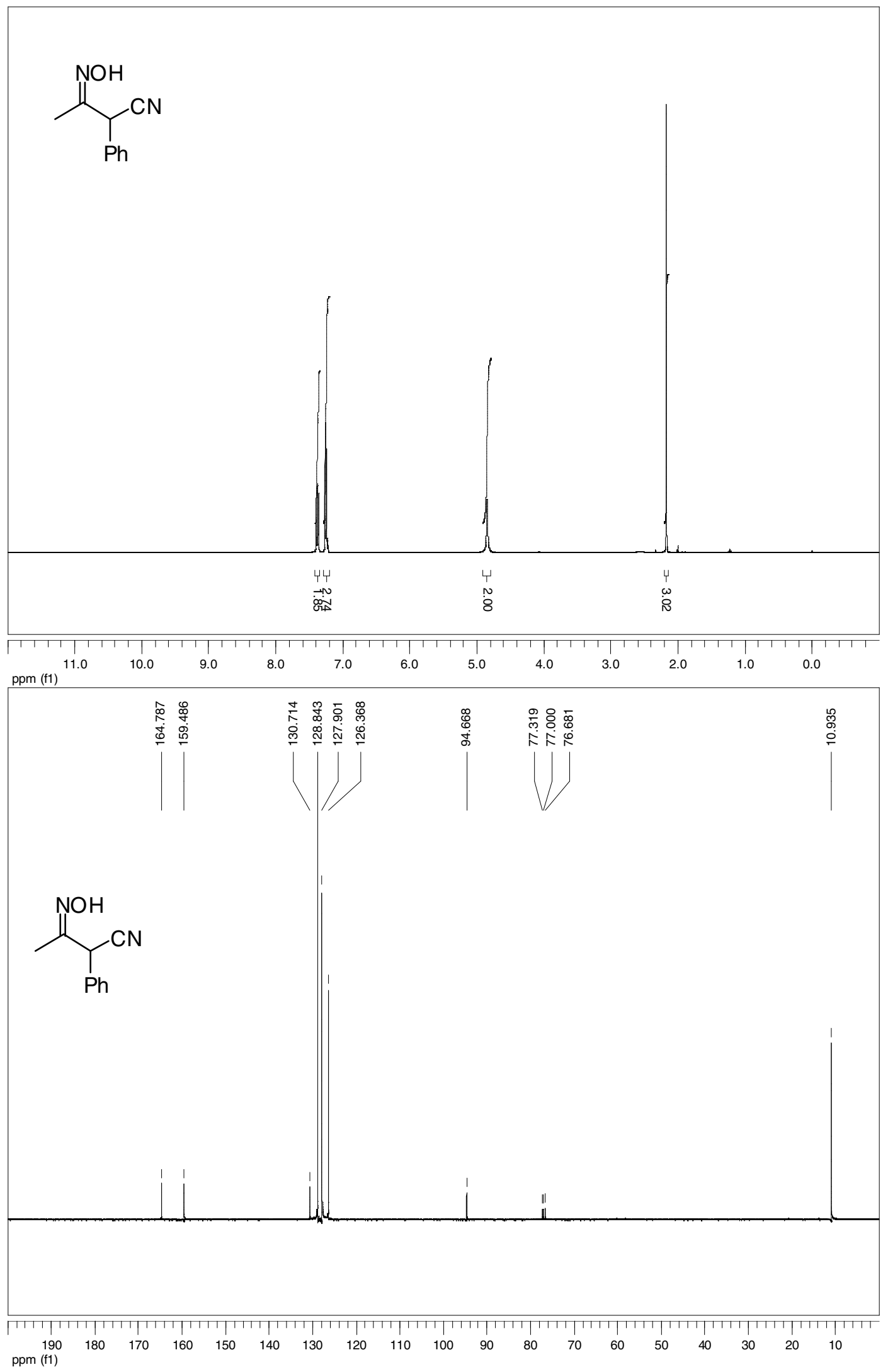

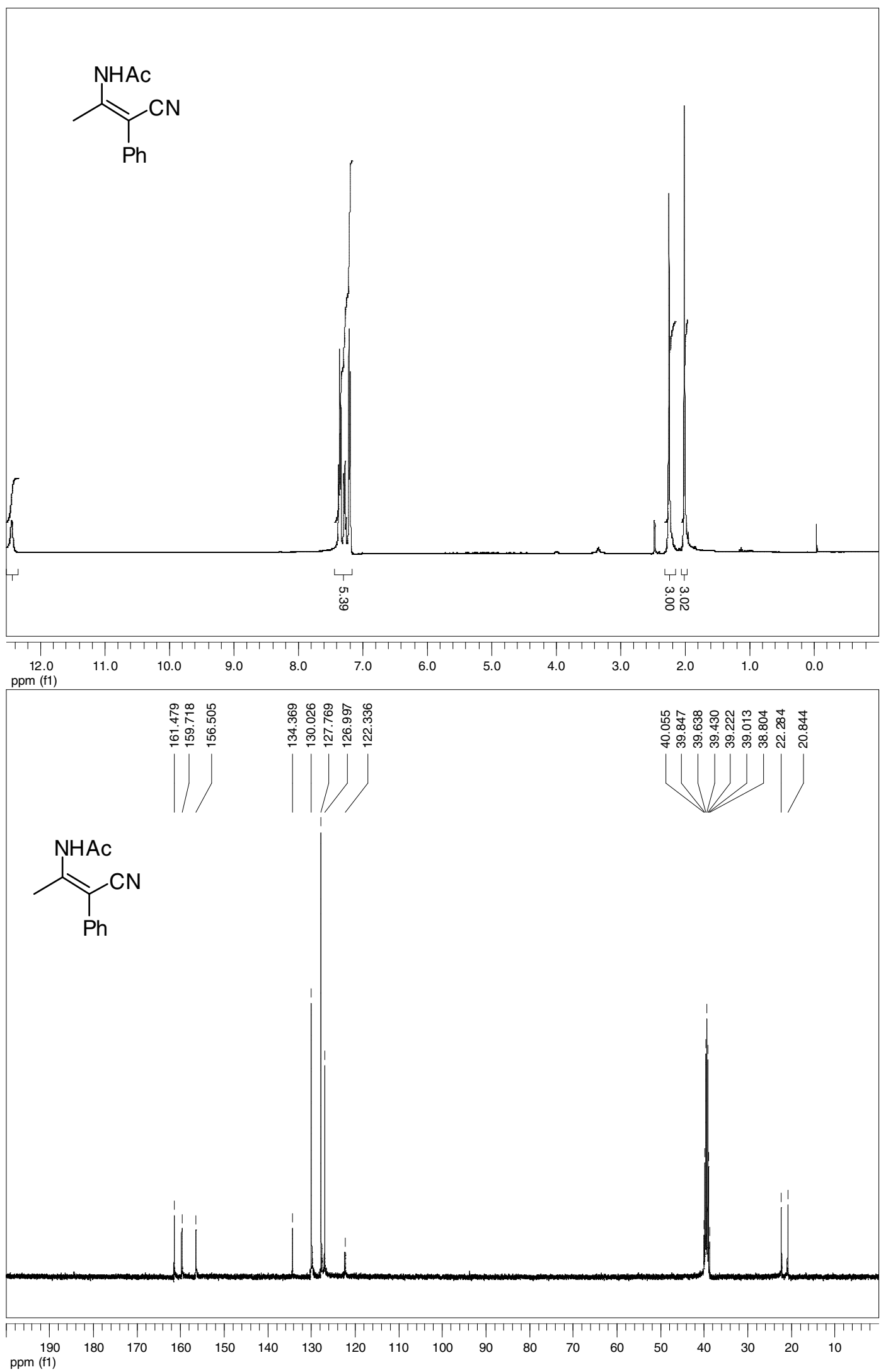

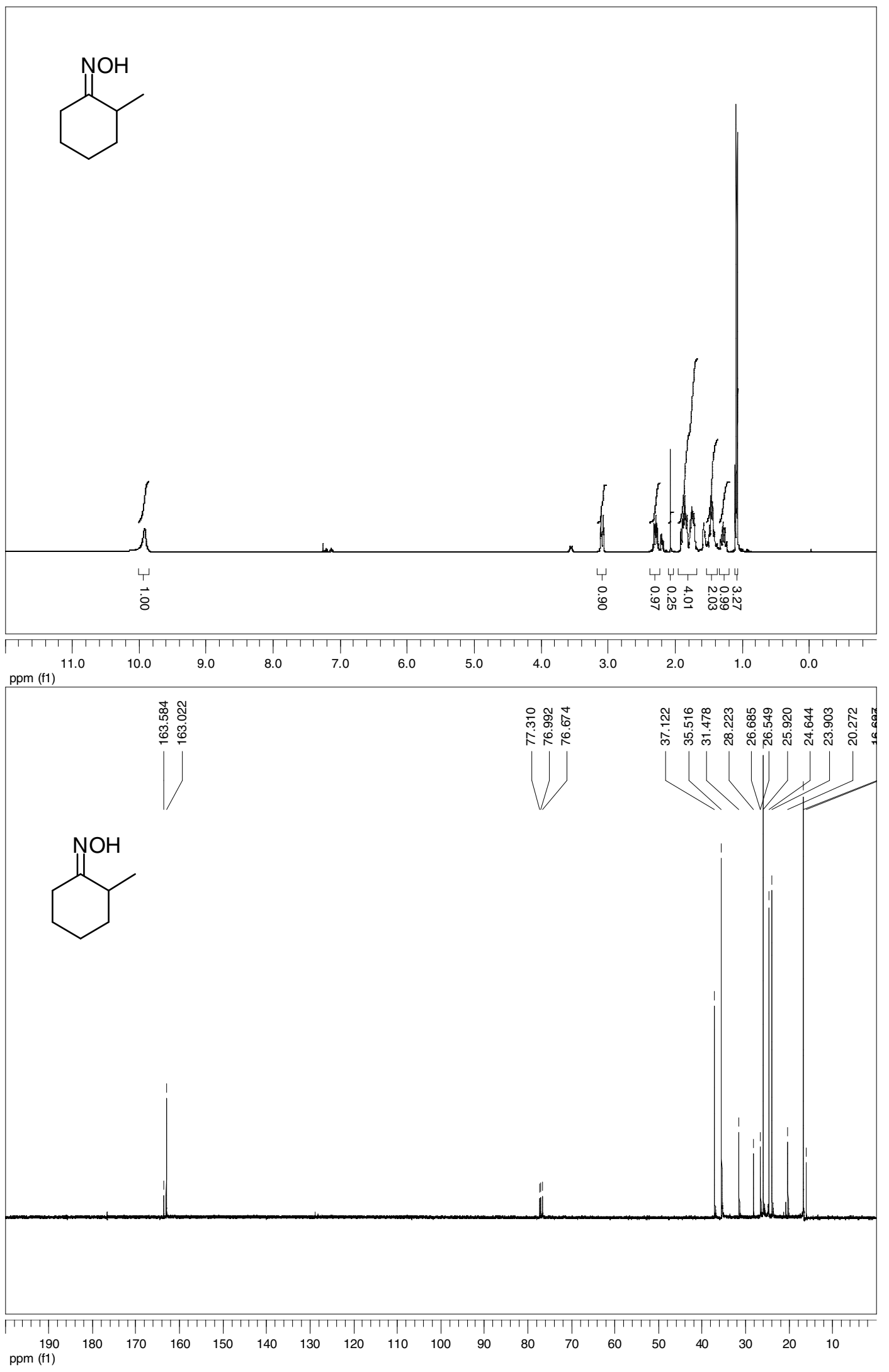


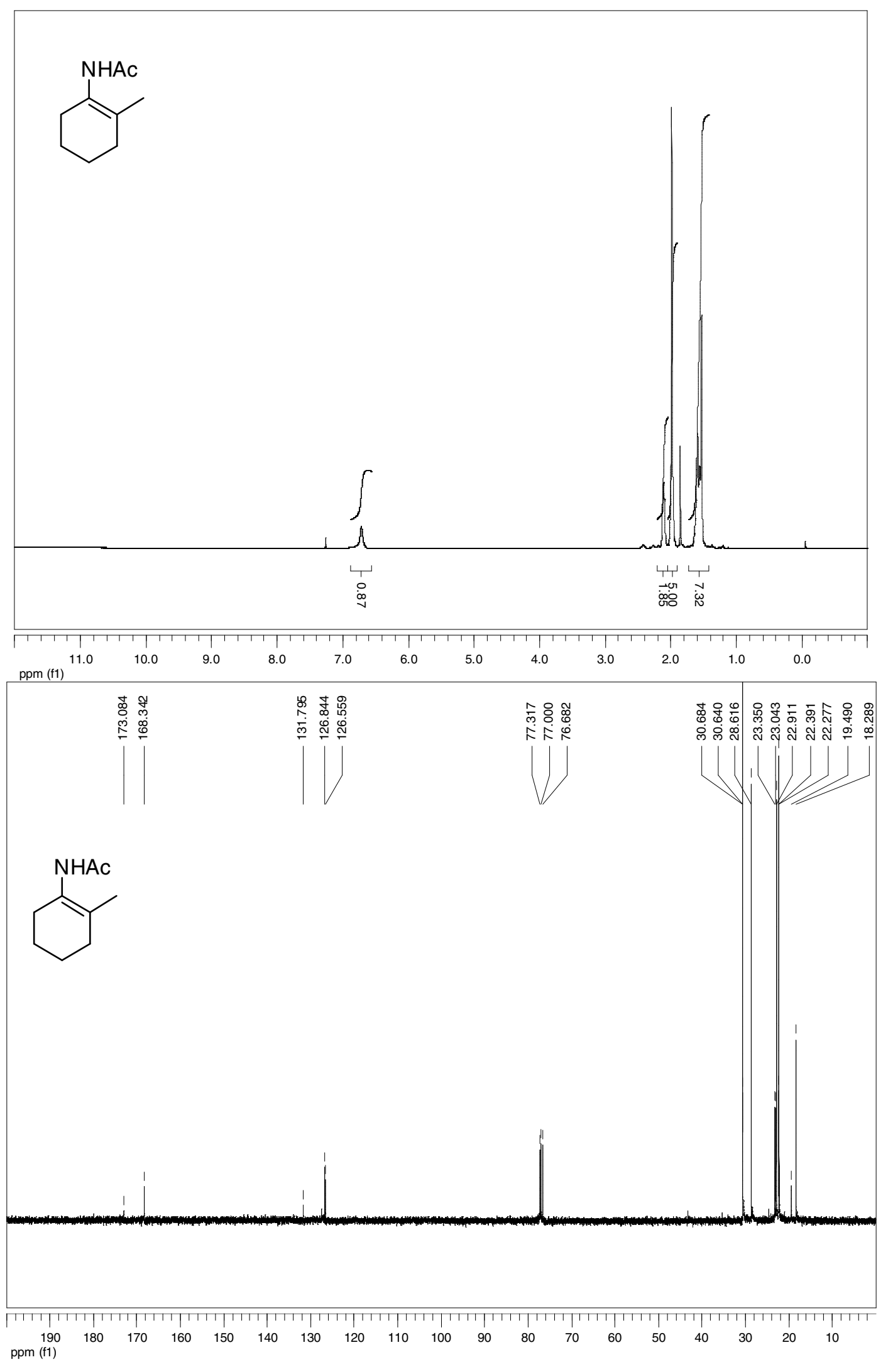




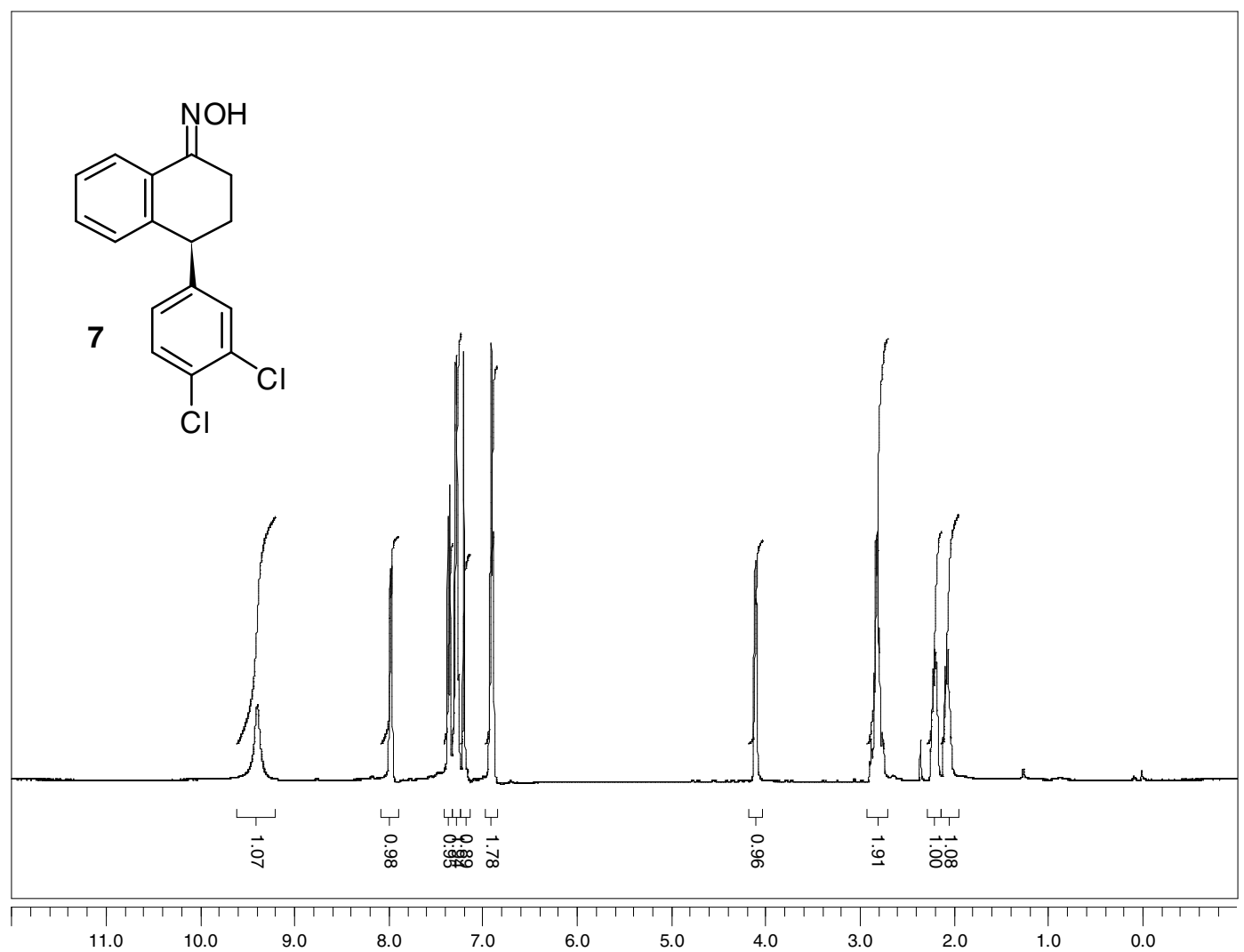

ppm (f1)

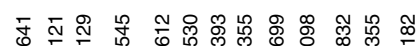

完辅守

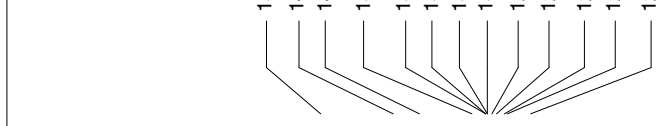

둥용

đิ

人下只

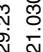

11

$\checkmark$<smiles>O=C1CCC(c2ccc(Cl)c(Cl)c2)c2ccccc21</smiles>
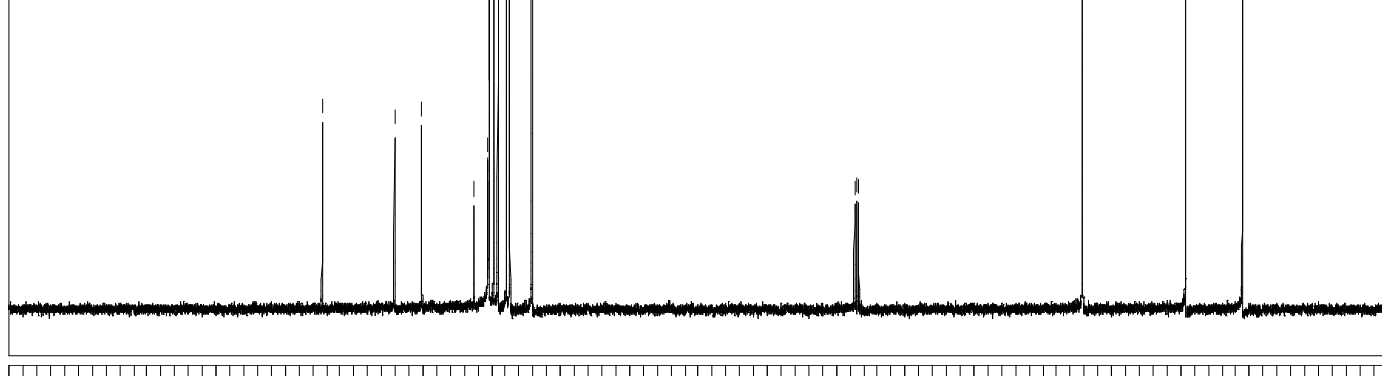

$\begin{array}{lllllllllllllllllll}190 & 180 & 170 & 160 & 150 & 140 & 130 & 120 & 110 & 100 & 90 & 80 & 70 & 60 & 50 & 40 & 30 & 20 & 10\end{array}$ ppm (t1) 

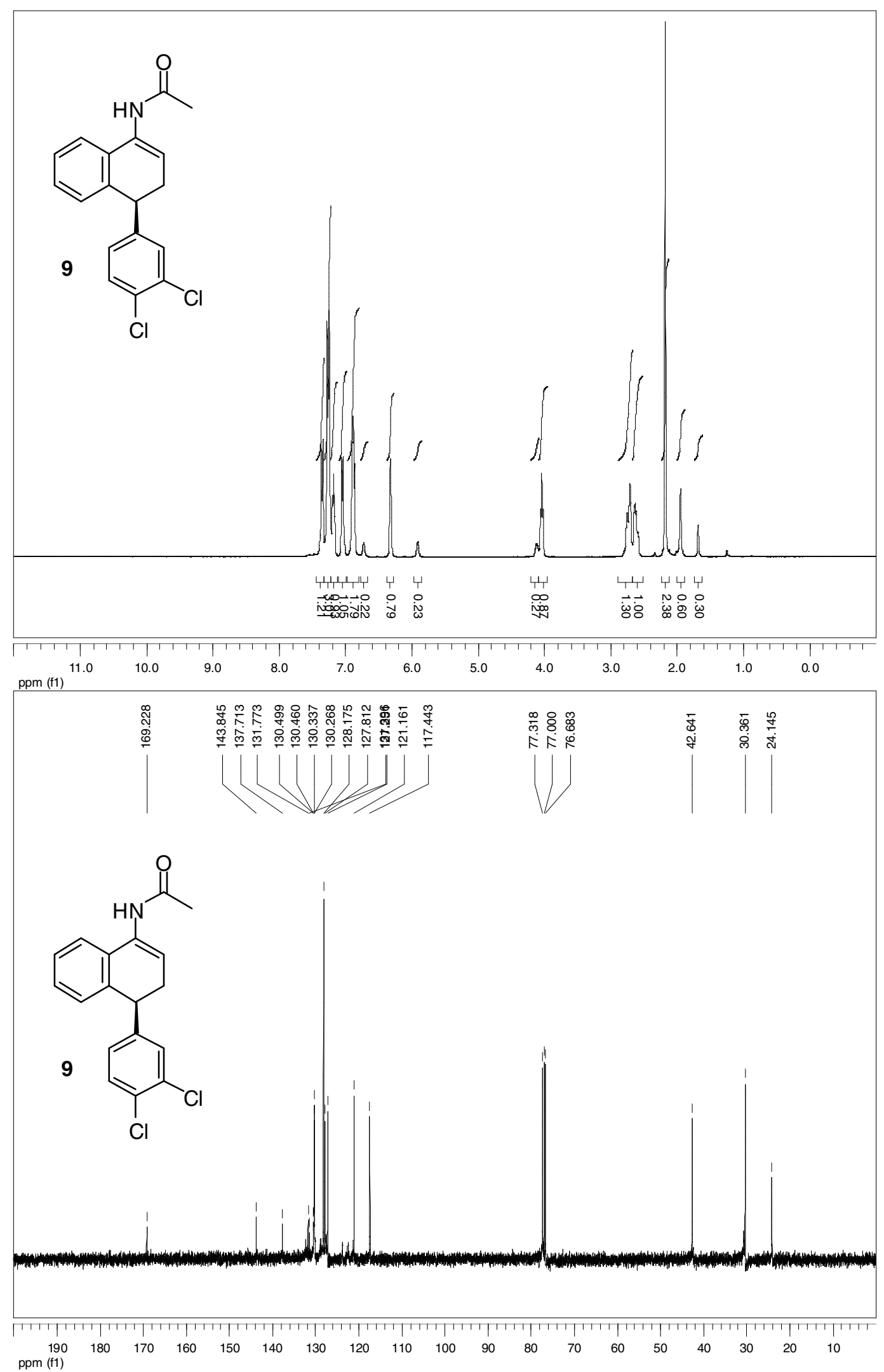